\title{
International Investment and Firm Performance: Empirical Evidence from Small Open Economies
}

Ville Kaitila* - John McQuinn ${ }^{* *}$ - Iulia Siedschlag ${ }^{* *}$ - Xiaoheng Zhang ${ }^{* *}$

Corresponding author: iulia.siedschlag@esri.ie

* ETLA - The Research Institute of the Finnish Economy

** ESRI - The Economic and Social Research Institute, Dublin; Department of Economics, Trinity College Dublin

Suggested citation: Kaitila, Ville; McQuinn, John; Siedschlag, lulia \& Zhang, Xiaoheng (1.3.2013). "International Investment and Firm Performance: Empirical Evidence from Small Open Economies".

ETLA Reports No 6. http://pub.etla.fi/ETLA-Raportit-Reports-6.pdf 
This paper is part of the SERVICEGAP project funded by the European Commission under the $7^{\text {th }}$ Framework

Programme, Grant Agreement No. 244522. We thank Mika Maliranta and participants in research presentations at a workshop and an international conference held at the Economic and Social Research Institute in Dublin for useful comments and suggestions.

ISSN-L 2323-2447

ISSN 2323-2447 (print)

ISSN 2323-2455 (online) 
Contents

$\begin{array}{ll}\text { Abstract } & 2\end{array}$

$\begin{array}{llr}\text { Introduction } & 3\end{array}$

2 Theoretical and empirical framework $\quad 3$

2.1 Productivity effects $\quad 5$

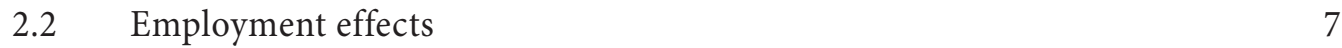

$\begin{array}{llr}3 & \text { Testable hypotheses } & 8\end{array}$

$\begin{array}{lll}4 & \text { Data and descriptive statistics } & 10\end{array}$

$5 \quad$ Empirical methodology 11

$6 \quad$ Empirical results $\quad 12$

6.1 Propensity score equation 12

6.2 Matching 13

6.3 The effects of foreign acquisitions on labour productivity and
employment growth

$\begin{array}{llr}7 & \text { Conclusions } & 18\end{array}$

$\begin{array}{lll}\text { Appendix A } & \text { Literature review } & 19\end{array}$

Appendix B Data imputation methodology 28

$\begin{array}{lll}\text { Appendix C Summary statistics } & 30\end{array}$

$\begin{array}{ll}\text { References } & 36\end{array}$ 


\section{Abstract}

This paper examines the causal link between foreign investment and firm performance in six small open economies in the European Union. Specifically, using micro data for manufacturing and services over the period 2001-2009, we analyse the effects of foreign mergers and acquisitions on labour productivity and employment growth up to five years after acquisition. Our results indicate that foreign investors tend to acquire larger firms in both manufacturing and services. Other characteristics of acquired firms differ across countries and between manufacturing and services. Taken together, our estimates suggest that foreign investment had stronger effects on firm performance in services in comparison to manufacturing.

Key words: Multinational firms, productivity, employment, propensity score matching

JEL: F16; F23; J24

\section{Tiivistelmä}

Tarkastelemme ulkomaisten sijoitusten ja yritysten kehityksen välistä yhteyttä kuudessa pienessä avotaloudessa Euroopan unionissa. Käyttämällä mikroaineistoja teollisuuden ja palvelualan yrityksistä vuosille 2001-2009 analysoimme ulkomaisten yritysostojen (mergers \& acquisitions) vaikutuksia yritysten työvoiman tuottavuudelle ja työllisyyden kasvulle viisi vuotta omistuksen siirtymisestä eteenpäin. Tulostemme mukaan ulkomaiset yritykset hankkivat omistukseensa keskimääräistä suurempia yrityksiä niin teollisuudessa kuin palvelualoillakin. Muiden ominaisuuksien osalta ostetuissa yrityksissä on maa- sekä sektorikohtaisia (teollisuus vs. palvelut) eroja. Kokonaisuutena ottaen ulkomaisilla sijoituksilla näyttää olevan suurempia vaikutuksia yritysten kehitykseen palvelualoilla kuin teollisuudessa.

Asiasanat: Monikansalliset yritykset, tuottavuus, työllisyys, propensity score matching

JEL: F16; F23; J24 


\section{Introduction}

A large theoretical and empirical literature has established that multinational firms perform better than those serving only domestic markets. ${ }^{1}$ While it is widely documented that the superior performance of foreign-owned firms is linked to their large endowments of intangible assets to compensate for a lack of local information and experience ${ }^{2}$, the difficulty is to identify the causal link between foreign ownership and firm performance, given other firm-specific confounding factors.

Foreign mergers and acquisitions (M\&A) imply a change of ownership and they thus provide a natural experiment which can help to identify the effects of foreign ownership on firm performance. While most existing analyses have focused on firms in manufacturing, the evidence for firms in services is scarce. To fill this evidence gap, we use two rich micro data sets ${ }^{3}$ and analyse the effects of foreign mergers and acquisitions on productivity and employment growth in manufacturing and service firms in six small European Union (EU) countries. ${ }^{4}$ This analysis uses propensity score matching combined with difference-in-difference estimators.

Our evidence indicates that, in both manufacturing and services sectors, foreign investors tend to acquire larger firms. Other characteristics of acquired firms differ across countries and between manufacturing and services.

Taken together, our estimates suggest that foreign investment had stronger effects on firm performance in services in comparison to manufacturing. Overall, we find that the effects of foreign investment on labour productivity and employment growth were country specific.

The rest of this paper is organised as follows. Section 2 reviews the relevant theoretical and empirical literature. Section 3 discusses testable hypotheses derived from Section 2. Section 4 presents our data and descriptive statistics. Section 5 explains our empirical methodology. Section 6 discusses our results. Finally, Section 7 concludes.

\section{Theoretical and empirical framework}

Existing theoretical and empirical evidence indicate that firms with international activities are more productive than other firms (see for example, Helpman, Melitz and Yeaple, 2004; Helpman, 2006). Exporting firms have been found to have higher productivity than firms that only serve their local market. ${ }^{5}$ Further up the productivity ladder, multinational firms ${ }^{6}$ which operate in more than one country are the most productive firms. Starting to export or investing abroad, per se, do not typically lead to faster productivity growth. Rather, higher productivity

\footnotetext{
See for example Helpman, Melitz and Yeaple (2004), and Helpman (2006).

See for example Caves (1974), and Dunning (1977).

Amadeus and Zephyr, provided by Bureau van Dijk, http://www.bvdinfo.com.

Austria, Belgium, Denmark, Finland, the Netherlands, and Sweden.

See for example Bernard and Jensen (1995).

See for example Bellak (2004) for a literature review on the performance gaps between multinational firms and their domestic counterparts. According to the theory of the multinational firm, the gaps are due to being a multinational rather than to the nationality of the firm. Empirical evidence shows that foreign ownership, per se, is a much less important explanatory factor than firm-specific assets and firm characteristics, such as industry, size, parent country and being multinational.
} 
firms self-select into internationalisation of activities. This higher performance is required in order to overcome the fixed distribution and servicing costs involved by exporting or investing abroad. In some cases, there may still be a boost to productivity after the internationalisation step has been taken, a learning effect.

The motivation for foreign direct investment (FDI) varies. The simplest assumption is that the firm expects that its future profits will rise. In more general terms, four broad motives for FDI have been considered: resource seeking, market seeking, efficiency seeking, and strategic asset seeking motives (Dunning, 1998). A foreign firm may wish to expand its markets and get firsthand local knowledge thereof, remove a competitor (takeover or closedown), acquire technology, patents or a local brand name, or take advantage of some competitive advantage in other countries such as lower production costs, skilled labour force or a good location vis-à-vis third markets. For firms in developed countries with high labour and other costs, producing in low-cost countries improves the price competitiveness of its products in the world markets.

Do foreign multinational firms have superior managerial skills, R\&D, technology, networks of suppliers, customers and distribution, etc., that when implemented in and extended to the acquired local company will lead to an increase in productivity? Typically this is what we expect, because firms that operate in the local market only, or even if they are exporters, are found on average to have lower productivity than multinational firms with presence abroad. Indeed, existing empirical evidence indicates that foreign-owned firms have higher productivity than domestic firms. However, if foreign multinationals acquire local firms that already have high capital intensity and productivity - so-called 'cherry picking', this superior productivity performance is not due to foreign-ownership per se. Nocke and Yeaple (2007) construct a general equilibrium model where depending on whether the firms differ in their internationally mobile or immobile capabilities, cross-border merger and acquisitions involves either the most or the least efficient firms.

On the other hand, it should not make that much of a difference whether the acquiring firm is a domestic or a foreign multinational firm if their home countries are approximately at the same level of development. However, there may be a difference if the countries are at very different levels of development. One would expect that if a firm from a more developed country acquires a local firm, productivity in the latter will rise, and vice versa. We will take a look at the existing evidence below.

In this paper, we will analyse the impact of foreign mergers and acquisitions on productivity and employment growth of acquired local firms. Especially in the short term, these may have opposite effects. If restructuring and performance-boosting measures ${ }^{7}$ are needed, shedding labour will lead to lower employment in the firm and most probably to higher labour productivity. ${ }^{8}$ However, if the labour and vocational training markets function properly this should not affect employment in the country in the medium term. On the other hand, higher productivity will lead to higher incomes and GDP per capita. Typically, existing studies have analysed total factor productivity which is also affected by the capital stock. Foreign-owned firms are often more capital-intensive than locally-owned firms. ${ }^{9}$

\footnotetext{
For example Girma (2005a) found that foreign acquisitions in the UK led to an increase in labour-use efficiency.

8 On the other hand, Piscitello and Rabbiosi (2005) report a positive effect on both labour productivity and employment following foreign takeovers in Italy.

$9 \quad$ For UK manufacturing, Schiffbauer, Siedschlag and Ruane (2009) found no effect of foreign mergers and acquisitions on total factor productivity (TFP). They found that following foreign mergers and acquisitions, labour productivity rose due to capital deepening. Furthermore, they found positive TFP effects when the acquirer was in R\&D-intensive industries and negative effects when the acquirer was in marketing-intensive industries.
} 
Early empirical analyses of firm-level effects of foreign acquisitions have used OLS estimators (see for example Aitken and Harrison 1999; Conyon et al. 2002a; Gioia and Thomsen 2004; Piscitello and Rabbiosi 2005; Fukao and Murakami 2005; Hanley and Zervos 2007; Balsvik and Haller 2010) or system GMM (see for example Harris and Robinson 2002; Gugler and Yurtoglu 2004; Harris 2009). To capture the causal link between foreign ownership and firm performance, more recent studies use propensity score matching combined with difference-indifference estimators. This empirical approach allows the comparison of firm outcomes in an acquired firm with counterfactual outcomes had the firm not been acquired. Since the counterfactual outcomes cannot be observed, they are generated using data on as similar as possible non-acquired firms (see for example, Girma 2005a, 2005b; Bellak, Pfaffermayr and Wild 2006; Girma, Kneller and Pisu 2007; Karpaty 2007; Huttunen 2007; Salis 2008; Bertrand and Zitouna 2008; Arnold and Javorcik 2009; Bandick and Hansson 2009; Schiffbauer, Siedschlag and Ruane 2009; Lipsey, Sjöholm and Sun 2010). A review of the main characteristics and results of these studies is shown in Appendix A.

While most existing analyses have focused on mergers and acquisitions of manufacturing firms, the evidence for service firms is scarce. However, the boundary between manufacturing and services have become less clear as many manufacturing firms are also major producers of services. The analysed samples vary with respect to representativeness, firm size, ownership definitions which may affect the results.

In most cases, the analysed firms are followed for at least two years before and after the acquisition. However, in some studies (Chen, 2011), acquisition effects are found only five years after the event, which suggests the need to extend the analysed period. Nevertheless, it is difficult to assess a priori how many years it takes for the possible effects of an ownership change to fully sink in.

\subsection{Productivity effects}

One much discussed and analysed issue is whether or not foreign firms 'cherry pick' the bestperforming firms in terms of productivity. However, this question is not unambiguously answered in the literature. Out of 31 studies analysed (see Table A1 in Appendix A), 14 conclude that foreign firms do acquire the most productive local firms or at least firms with above-average productivity. On the other hand, two studies find evidence that foreign firms instead acquire local firms with below-average productivity, ${ }^{10}$ six conclude that there was no difference in terms of productivity, and four reported mixed results. Five studies do not analyse the issue. ${ }^{11}$ Further, as shown in Table A.2 in Appendix A, foreign firms typically target local firms with a highly skilled labour force. Overall, most evidence suggests that foreign investors tend to acquire high productivity firms.

Evidence from the reviewed literature indicates that productivity growth will be higher after the acquisition and that the level of productivity will then stay at a higher level. ${ }^{12}$ The boost

\footnotetext{
10 According to Gioia and Thomsen (2004), foreign buyers tend to buy poor performers in Denmark as measured by return on assets and factor productivity. They argue that this is because of information disadvantages leading to a double "lemons problem". Bertrand and Zitouna (2008) find evidence of lemons picking in French manufacturing industries. Similar evidence is found by Girma and Görg (2007) for the UK electronics and food industries, and Harris (2009) for UK service industries.

11 Ten of the studies referred to in Table A.1 use UK data. However, even these find different answers to the question about cherrypicking.

12 Also negative productivity effects, regardless of the home country of the acquirer, have been found (see for example Hanley and Zervos 2007, for UK manufacturing).
} 
can be due to restructuring of inefficient plants, which involves labour shedding and new capital investments. ${ }^{13}$ While the productivity boost is likely to be temporary, especially in developed countries, productivity differentials may persist longer in developing countries.

A number of studies analysed both the productivity level and growth effects of foreign acquisitions (for example, Aitken and Harrison 1999; Conyon et al. 2002a). Conyon et al. (2002a) found that the level and growth effects were both positive only in the case of US-based multinational firms. Multinational firms from other parts of the world had a positive effect on the productivity level of acquired firms but no productivity growth effect. Fukao, Ito and Kwon (2005) found that Japanese firms acquired by US- and European-based multinational firms had faster TFP levels as well TFP growth rates than other owners, i.e. domestic Japanese or other foreign firms. The findings by Fukao and Murakami (2005) are mostly in line with these results. Arnold and Javorcik (2009), using micro data from Indonesia, found that the rise in productivity in the acquired plants was mostly a level effect.

However, the productivity boost of foreign acquired firms can be conditional on the country of origin of multinational firms. Empirical evidence to support this hypothesis has been provided among others, by Girma (2005b), Harris (2009) and Criscuolo and Martin (2009) for the UK, Fukao, Ito and Kwon (2005) for Japan, Piscitello and Rabbiosi (2005) for Italy, Bertrand and Zitouna (2008) for France, and Chen (2011) for the United States.

US-based multinationals are typically found to have had a bigger impact on the acquired firms than multinationals from other parts of the world. According to Bloom, Sadun and Van Reenen (2012), US multinationals in Europe experienced higher productivity from using information technologies (IT) than non-US multinationals. Furthermore, local firms taken over by US multinationals increased the productivity of their IT. This did not happen in non-US multinationals. However, other results have also been reached. Using UK data, Criscuolo and Martin (2009) found that acquisitions by US-based multinationals do not differ from acquisitions by other multinationals. Piscitello and Rabbiosi (2005) found for Italy that positive effects from acquisitions are higher when the acquirer is a multinational firm based in continental Europe. If it is a US- or a UK-based multinational firm, the effects are still positive but weaker 'due to a larger cultural distance', according to the authors.

What then are the effects in the US where average productivity is the highest in the world? Using data on US firms, Chen (2011) found that multinational firms from other industrialised countries had a positive impact on labour productivity in the acquired US firms, but multinational firms from developing countries had a negative impact, both relative to domestic US acquisitions. On the other hand, according to the results by Chari, Chen and Dominguez (2009), multinational firms from emerging countries will shed labour and raise profitability in acquired US firms.

Girma, Görg and Pisu (2008) found evidence of significant horizontal spillovers from exportoriented multinationals to foreign-acquired domestic exporters, but not to acquired non-exporters in the UK. ${ }^{14}$ They argue that this is due to a greater absorptive capacity, as shown by higher productivity in exporting firms than in firms that only sell to the domestic market.

\footnotetext{
3 Piscitello and Rabbiosi (2005) as well as Arnold and Javorcik (2009) find that there has been a rise in both labour productivity and employment in foreign-acquired Italian and Indonesian firms, respectively.

14 Positive spillovers to other firms are also possible. Using Lithuanian firm-level data, Javorcik (2004) finds evidence of positive productivity spillovers arising through backward linkages in partially but not-fully-owned foreign projects.
} 
With a greater absorptive capacity, an exporter has high enough know-how to be able to take advantage of the more extensive resources and higher productivity of its new owner. ${ }^{15}$ Girma, Greenaway and Wakelin (2001) found evidence that UK firms with low initial productivity operating in low-skill sectors with low foreign competition gain less from or may even be damaged by foreign presence. According to Girma, Kneller and Pisu (2007), UK firms with higher pre-acquisition productivity first experience larger efficiency gains after the acquisition. However, two years into the acquisition, the rate of learning is instead greater the lower the pre-acquisition TFP of the acquired firm. Thereafter, growth rates converge. The authors also find that positive horizontal spillovers arise only from export-oriented multinationals. Instead, domestic-market-oriented multinational firms generate positive spillovers through backward linkages for both domestic exporters and non-exporters. ${ }^{16}$ Aitken and Harrison (1999) found that in Venezuela increases in foreign ownership decreased productivity in fully domestically owned firms in the same industry. They also did not find any evidence of technology spillovers from foreign to domestically owned firms.

Aitken and Harrison (1999), Blomström and Sjöholm (1999), Chhibber and Majumdar (1999), Dimelis and Louri (2002), and more recently Greenaway, Guariglia and Yu (2009) analysed whether the degree of foreign ownership affects firms' performance. They analysed firms in Venezuela, Indonesia, India, Greece and China, respectively. According to their results, the degree of ownership matters in India, Greece, China (inverted U-shaped relationship with joint ventures performing the best), and for small firms in Venezuela, but it does not matter in Indonesia. The emerging market status of these countries may affect the results compared with similar studies in developed countries. Using OLS and difference-in-difference estimators, Ilmakunnas and Maliranta (2004) find no significant difference between a 20 per cent and a 50 per cent foreign ownership in Finland. Also Fukao, Ito and Kwon (2005) find no differences between a 33.4 per cent-owned and a majority-owned foreign firm in Japan.

Most existing studies use data on manufacturing firms, and even if non-manufacturing firms are included, no specific results for service sector firms are given. There are some exceptions. According to Fukao et al. (2008), domestic acquisitions had a negative impact on TFP growth in Japan's non-manufacturing firms. Using UK data, Harris (2009) found that there are TFP gains in US- and EU-acquired service sector plants, but that the effects dissipate over time. In 'other' foreign-owned ${ }^{17}$ plants, he found a 10 per cent longer-term gain. Schiffbauer, Siedschlag and Ruane (2009) found no TFP effects in the UK service sectors.

\subsection{Employment effects}

The evidence with respect to the employment effects of foreign acquisitions vary more than the effects of foreign acquisitions on productivity. It is probably more intuitive that productivity rises following a foreign acquisition, while employment effects can be either positive or negative. ${ }^{18}$

\footnotetext{
15 Also Girma (2005b) found that US- and EU-acquisitions result in higher TFP improvements the higher the absorptive capacity of the acquired firm. With high enough initial productivity rate of technology transfer due to the foreign acquisition starts to decline, however.

16 Bandick (2011) found that targeted Swedish MNEs and non-MNEs have faster TFP growth after vertical foreign acquisition but no such impact after a horizontal foreign acquisition.

17 That is other than the EU, the USA, Canada, Australia, New Zealand, South Africa or South East Asia.

18 Of course the plant may also be shut down in which case the loss in employment is total. Sometimes the studies analyse only surviving firms. We have not referred to results for closedown in this survey.
} 
Faster employment growth after acquisition is found by Piscitello and Rabbiosi (2005) for Italy, Gong, Görg and Maioli (2007) for privatised Chinese firms, Almeida (2007) for Portugal, Arnold and Javorcik (2009) as well as Lipsey, Sjöholm and Sun (2010) for Indonesia, Balsvik and Haller (2010) for Norway, and Bandick and Görg (2010) as well as Bandick and Karpaty (2011) for Sweden. Negative employment effects have been found by, among others, Conyon et al. (2002a) for the UK, Csengödi, Jungnickel and Urban (2008) for Hungary, and Chari, Chen and Dominguez (2009) for the United States.

In some studies, the employment effects have been found to depend on the sector, the size of the acquired firms, or the skill-level of the labour force. Girma (2005a) found negative employment effects in larger acquired British firms and positive effects in smaller ones. Using Swedish data, Bandick and Görg (2010) found that the increase in employment was larger in exporters and smaller in acquired MNEs, but both occurred only if the takeover was vertical. There were no effects if the target was a purely domestic firm or if the acquisition was horizontal.

Huttunen (2007) as well as Lehto and Böckerman (2008) found negative employment effects of foreign acquisitions in Finland albeit with some variation depending on the skill groups and sectors. Huttunen's results indicate that the share of highly-skilled workers declined in the post-acquisition period. On the other hand, Bandick and Hansson (2009) found that in Sweden, the relative demand for skilled labour rose in foreign-acquired non-multinational firms (but not in acquired multinational firms). Also Bandick and Karpaty (2011) found an increase in skilled employment in Sweden following foreign acquisitions. Girma and Görg (2004) found slower employment growth in the UK electronics industry, in particular for unskilled labour, but no significant effects in the food sector. Lipsey, Sjöholm and Sun (2010) found that in Indonesia, in foreign acquired firms, blue-collar employment grew faster than white-collar employment. Only few studies report results for service sectors. Fukao et al. (2008) report a fall, albeit temporary, in non-manufacturing employment following a foreign takeover. Lehto and Böckerman (2008) found some evidence of negative employment effects in construction and other services in Finland, but no effects in trade, hotels and restaurants. Harris (2009) found that overall, post-acquisition employment changed very little in the UK service sectors.

\section{Testable hypotheses}

The reviewed literature suggests a number of testable hypotheses with respect to the motivation and types of firms acquired by foreign investors as well as the post-acquisition performance of foreign acquired firms.

According to the managerial hubris hypothesis (Roll, 1986), managers may use mergers and acquisitions to fulfil their desires to maximise firm size. In this case, we cannot make an $e x$ ante assumption as to the efficiency of acquired firms or their future development. According to the management's comparative advantage (or managerial-discipline) hypothesis, "lemons" (i.e. bad performers) are acquired and their performance should increase after acquisition. According to the synergy effects hypothesis, "cherries" (i.e. good performers) are acquired and their performance should increase after acquisition. The latter two hypotheses maintain that the aim of the acquisition is to maximise profits. Productivity is expected to rise when foreign investors transfer their superior firm-specific advantages to their foreign affiliates. This is the 
firm specific-advantage hypothesis. (See for example Gugler et al., 2003; Fukao et al., 2008; and Balsvik and Haller, 2010). Profit-maximising managers versus empire-builders are also discussed by Jensen (1986) and Conyon et al. (2002b.)

It has also been suggested that FDI may not be driven by high performance firms exploiting their advantage abroad, but instead by firms trying to gain access to superior foreign technology. This is the technology sourcing hypothesis. (Branstetter, 2001; Keller, 2004; and Criscuolo and Martin, 2009).

Nocke and Yeaple (2007) distinguish between firms' mobile and non-mobile capabilities that determine whether cross-border mergers and acquisitions involve either the most or the least efficient firms. In industries in which the source of firm heterogeneity is due to internationally mobile (non-mobile) factors foreign acquisitions lead to a more substantial (less dramatic) improvement in the acquired firm's performance than domestic acquisitions. This implies that the possibility of productivity spillovers to the acquired firm is the highest if the acquirer firm is in an R\&D-intensive industry and the lowest or even negative if it operates in a marketing-intensive industry.

The productivity impact on the acquired firm may depend on its absorptive capacity, i.e. the level of education of its employees (see for example, Nelson and Phelps, 1966). Thus, it may be that only a firm with higher productivity when acquired will be able to absorb the more advanced technology of the foreign owned firm (Lapan and Bardhan, 1973). Consequently, an acquired exporting firm may receive greater benefits than an acquired local firm, something that e.g. Bandick and Görg (2010) test. On the other hand, it has also been suggested that a large technological gap between the foreign owned firm and the acquired firm may lead to a larger boost in productivity of the latter (Findlay, 1978). This has been analysed for example, by Girma (2005b).

The effect of foreign acquisition on the performance of the acquired firm may vary depending on the home country of the foreign investor. A foreign owned firm from a more developed industrialised country may be able to transfer more up-to-date technology to the acquired firm thus leading to better productivity performance than a foreign owned firm from a developing or emerging economy. This can be tested by including information about the home country of the foreign owned firm. Also, firms acquired by developing-country multinationals may suffer decreases in employment compared with acquisitions from a developed country (Chen, 2011; and Fortanier and Moons, 2011).

Industry type and firm size. Following Caves $(1971,1974)$, horizontal FDI where the local subsidiary produces the same type of goods as its multinational firm parent, will occur in industries with product differentiation and relatively large firm size. Also, the more foreign subsidiaries in the sector, the higher technical efficiency will be and more technology transfers to domestic firms. This should lead to faster productivity developments.

FDI type and labour demand. Mattes (2010a, 2010b) analyses the following hypotheses: (i) horizontal FDI has a positive impact on labour demand, while vertical FDI has a negative one; (ii) FDI has a positive impact on the demand for high-skilled labour and a negative impact on the demand for low-skilled labour; ${ }^{19}$ (iii) highly productive and unproductive firms are subject to

19 The distinction between greenfield entries and acquisitions may play a role here: see for example Bartel and Lichtenberg (1987). 
foreign takeovers, while average performers are not (i.e. U curve relationship); and (iv) firms with a large market share are subject to foreign takeovers.

If the foreign owned firm transfers skill-biased technology, this will favour the type of labour that is intensive in the required skills. The effect may or may not favour labour with advanced skills. High-skill activities, such as many headquarter and R\&D activities, may well be moved out of the country. (See e.g. Bandick and Hansson, 2009; and Bandick and Karpaty, 2011.)

Lehto and Böckerman (2008) hypothesise that especially in non-labour-intensive services a domestic buyer - located in the same market as the target firm - may have a greater interest than a foreign owned firm to buy another firm to limit competition. This may have a larger negative impact on employment.

Dimelis and Louri (2002) analyse several hypotheses in relation to the effects of international investment on firm performance: (i) labour productivity is influenced by the degree of foreign ownership; (ii) the degree of foreign engagement in an industry affects the extent of productivity spillovers; and (iii) the effect of foreign involvement is different at various points of the conditional distribution of productivity.

\section{$4 \quad$ Data and descriptive statistics}

We use firm level data from the Bureau van Dijk's Amadeus and Zephyr datasets for firms in the following six small and open EU countries: Austria, Belgium, Denmark, Finland, the Netherlands and Sweden. The period under examination covers the years 2001 to 2009. Amadeus is an extensive dataset including information on firm characteristics, financial performance and legal structure while Zephyr has detailed information on mergers and acquisitions, notably cross-border transactions. Using common identifiers we combine these two datasets for our study. Bureau van Dijk categorises company legal form into three broad categories: limited companies, limited liability companies and other forms. We use data on unconsolidated accounts for only the first two categories to allow comparability across countries as these two categories correspond to public and private limited companies respectively. Firms are classified according to their two-digit NACE code (Rev.1), which enables us to separate service from manufacturing firms and explore heterogeneity between the two sectors.

We define a foreign acquisition as any ownership stake passing over a threshold of 10 per cent of total shareholding in line with officially recognised definitions of foreign direct investment. ${ }^{20}$ We only consider medium and larger firms. These are defined by Amadeus as firms fulfilling at least one of the following conditions: the number of employees is greater than 15 , operating revenue is greater than one million euros and/or total assets are greater than two million euros. Financial institutions and insurance companies are excluded from the Amadeus database due to compatibility issues with respect to the format of financial accounts. In our analysis, using available data, we construct the following variables: the age of the firm, employment, the ratio of debt to fixed assets, tangible fixed assets per employee (capital-labour ratio), turnover per employee (labour productivity), employment growth rate, turnover per employee growth rate (labour productivity growth), a foreign acquisition dummy (binary var-

For a definition of FDI see International Monetary Fund (1993). 
iable equal to one in the year where the acquirers' stake passes 10 per cent), and industry, region and year dummies. We use industry producer price indices at the two digit level to deflate manufacturing firm monetary variables with 2005 as the base year and a GDP deflator with 2006 as the base year for service firms. Finally, our sample is restricted to non-negative observations for tangible fixed assets and the number of employees while debt is restricted to values equal to or greater than zero.

The available data are limited by missing values. Assuming that missing data are randomly missing, we generate these data using a weighted hotdeck methodology. This is a multiple imputation process whereby five datasets are generated using a stochastic process and combined using the Rubin's Rule. ${ }^{21}$ A detailed description of the imputation method is given in Appendix B.

Summary statistics are presented in Tables C1-C6 in Appendix C. These summary statistics show a good deal of variation both between and within countries although less variation exists between manufacturing and services.

\section{$5 \quad$ Empirical methodology}

This paper uses a propensity score matching combined with difference-in-difference estimators (Heckman et al. 1997) to examine the causal effect of foreign acquisition on firm productivity and employment. To this purpose, we first estimate the foreign acquisition (the treatment, D) propensity conditioned by the observed firm characteristics, X, using a probit propensity score equation. We then use the propensity score to match foreign acquired and domestic non-acquired firms assuming conditional independence, i.e. that foreign acquisitions is only determined by observables $\mathrm{X}$ and by no any unobservable characteristics. In combination with this assumption, a substantial overlap between the propensity score of the treated and untreated firms, also referred to as the common support assumption, allows matching non-acquired (control) firms to acquired (treated) firms such that:

$$
\left(Y_{1}, Y_{0}\right) \perp D \mid p(X) \text { and } 0<p(X)<1
$$

$\mathrm{Y}_{1}$ is the firm outcome following foreign acquisition and $\mathrm{Y}_{0}$ is the firm outcome under nonacquisition. $\mathrm{p}(\mathrm{X})$ is the propensity score estimated using a set of observed characteristics, $X . D \in\{0,1\}$ is the treatment indicator where 0 indicates non-acquired control firms and 1 indicates foreign acquired firms. Thus, assuming conditional independence, outcomes for foreign acquired and for non-acquired firms are independent of treatment when matched on the propensity score with common support.

To predict the foreign acquisition propensity, we use the following firm characteristics: the number of employees and its square term; the debt-to-fixed-assets ratio; the firm's age and its square term; the capital-to-labour ratio; and industry (3 digit NACE Rev. 1 classification), region and year fixed effects. These variables are lagged where possible by one year except for age and its square term. The sample is also weighted by size classes ${ }^{22}$ which divide firms ac-

1 See Andridge and Little (2010).

22 Weights are calculated on the basis of information provided by the Eurostat. 
cording to the number of employees working at the firm as follows: firms with: 10-19 employees; 20-49 employees; 50-249 employees and firms with more than 250 employees.

Following the estimated foreign acquisition probability, foreign acquired firms are matched to the domestic non-acquired firms on the common support. We employ one-to-one nearest neighbour matching with replacement using a 0.005 caliper to reduce the likelihood of poor matches. ${ }^{23}$ We impose the common support assumption, which implies that foreign acquired firms having a propensity score higher than the maximum or less than the minimum of the propensity score of the domestic non-acquired firms are dropped. In addition, we perform balancing tests after matching to test the null hypothesis that sufficient overlap exists on the common support between foreign acquired firms and the control group. The balancing tests are similar to Arnold and Javorcik (2009) including t-tests of the equality of means based on a regression of the variable on the treatment indicator, as well as a F-test of the quartic function of the propensity score and its interactions with the treatment dummy.

Finally, we use a difference-in-differences approach to determine the causal effect of foreign acquisition on firm performance. This is achieved by calculating the difference between outcomes of foreign acquired and domestic non-acquired firms but also the difference over time within outcomes for foreign acquired and domestic non-acquired firms. This empirical approach gives the growth rate of firm outcomes as a result of foreign acquisition. Calculating the difference over time allows us to control for unobserved time-invariant characteristics having already controlled for observed heterogeneity in the propensity score stage described above. The difference-in-differences equation is given by:

$$
D_{t, t-1}(X)=E\left(Y_{1 t}-Y_{0, t-1} \mid X, D=1\right)-E\left(Y_{0 t}-Y_{0, t-1} \mid X, D=0\right) \text { for } X \in S \text {, }
$$

where $S$ is the common support between the treated and control groups. Equation (2) shown above gives the average treatment effect on the treated (ATT) or the causal effect of foreign acquisition.

\section{$6 \quad$ Empirical results}

\subsection{Propensity score equation}

We first consider the estimates of the propensity score equation. ${ }^{24}$ These estimates indicate that foreign investors tend to acquire larger firms in Belgium, Denmark, Finland, and Sweden, in manufacturing as well as services. In contrast to services, it appears that larger firms in manufacturing are acquired at a decreasing rate. These results are in line with Gioia and Thomsen (2004) for Denmark and with findings of Bandick and Görg (2010) and Bandick and Karpaty (2011) for Sweden. We find that foreign investors "cherry picked" higher productivity service firms in Belgium and Denmark, while in Austria lower productivity services firms were more likely to be acquired by foreign investors (in contrast to findings by Bellak, Pfaffermayr and Wild, 2006). In manufacturing, we find that in Finland foreign investors "cher-

\footnotetext{
23 Using the nearest neighbour matching leads to less bias as this method only uses the control observation closest in distance to match the treated observation.

24 Available on request from the authors.
} 
ry picked" high productivity firms (these results are in line with Ilmakunnas and Maliranta, 2004; and Huttunen, 2007) while in the Netherlands, lower productivity firms were more likely to be acquired by foreign investors.

Also, we find that in Belgium and Denmark, foreign investors in manufacturing were more likely to acquire firms with higher debt-to-fixed-assets ratios. In addition, older service firms were more likely to be acquired in Denmark and Finland, although at a decreasing rate while foreign acquisition of manufacturing firms was more likely for younger firms. The evidence also suggests that in Belgium and Finland, foreign investors in manufacturing tended to acquire more capital-intensive firms.

\subsection{Matching}

We discuss next the matching results using the nearest neighbour matching method. It should be noted that, while the number of foreign acquired firms in the acquisition year and the first two years following acquisition are approximately comparable in the number of matched firms, these numbers decline rapidly thereafter reducing the comparability of the group of firms under examination particularly in the third, fourth and fifth years following acquisition. The results of the balancing tests show few statistically significant differences, thus validating the common support assumption discussed above. ${ }^{25}$

Labour productivity is measured as turnover per employee as in Conyon et al. (2002a) ${ }^{26}$ and Chen (2011). ${ }^{27}$ In other studies, labour productivity has been measured as value added per employee (for example, Piscitello and Rabbiosi, 2005; Mattes, 2010a; Csengödi, Jungnickel and Urban, 2008). However, data on value added is not available for Denmark in the Amadeus data set. Previous studies using both measures of labour productivity found that foreign acquisition had a positive impact on both labour productivity level as well as productivity growth. Nevertheless, Mattes (2010), using propensity score matching found no significant effect. However, these studies focus only on manufacturing firms whereas our results show some instances where results differ between manufacturing and service firms within countries in addition to heterogeneity between countries.

\subsection{The effects of foreign acquisitions on labour productivity and employment growth}

The estimates of the effects of foreign acquisitions on labour productivity growth in service firms are shown in Table 1.

Overall, the estimates suggest no general pattern across the analysed countries. In the acquisition year, foreign acquisition led to significantly higher labour productivity growth in Denmark, significantly lower labour productivity growth in Belgium and the Netherlands and had no significant effect on labour productivity growth in Austria, Finland and Sweden. Three years after acquisition, the positive and significant effect of foreign acquisition on la-

\footnotetext{
25 Results available on request from the authors.

26 Conyon et al.(2002a) explore both growth and level effects.

27 Chen (2011) examines growth effects only.
} 


\begin{tabular}{|c|c|c|c|c|c|c|}
\hline \multirow{2}{*}{$\begin{array}{l}\text { Table } 1 \\
\text { Country }\end{array}$} & \multicolumn{6}{|c|}{$\begin{array}{l}\text { The effect of foreign mergers and acquisitions on labour productivity } \\
\text { growth - service firms }\end{array}$} \\
\hline & Austria & Belgium & Netherlands & Denmark & Finland & Sweden \\
\hline Year 0 & $\begin{array}{l}-0.123 \\
(0.134) \\
N=191\end{array}$ & $\begin{array}{l}-0.186^{* * *} \\
(0.057) \\
N=731\end{array}$ & $\begin{array}{l}-0.164^{*} \\
(0.085) \\
N=643\end{array}$ & $\begin{array}{l}0.212^{* *} \\
(0.089) \\
\mathrm{N}=500\end{array}$ & $\begin{array}{l}-0.011 \\
(0.072) \\
N=325\end{array}$ & $\begin{array}{l}-0.047 \\
(0.044) \\
N=767\end{array}$ \\
\hline Year 1 & $\begin{array}{l}0.005 \\
(0.120) \\
N=186\end{array}$ & $\begin{array}{l}-0.234^{* * *} \\
(0.062) \\
N=651\end{array}$ & $\begin{array}{l}0.090 \\
-0.097 \\
N=552\end{array}$ & $\begin{array}{l}0.271^{* * *} \\
-0.086 \\
\mathrm{~N}=481\end{array}$ & $\begin{array}{l}-0.108 \\
-0.070 \\
N=287\end{array}$ & $\begin{array}{l}-0.032 \\
-0.053 \\
N=703\end{array}$ \\
\hline Year 2 & $\begin{array}{l}0.195 \\
(0.155) \\
N=139\end{array}$ & $\begin{array}{l}-0.151^{* *} \\
(0.065) \\
N=523\end{array}$ & $\begin{array}{l}-0.224^{* *} \\
(0.107) \\
\mathrm{N}=449\end{array}$ & $\begin{array}{l}0.155 \\
(0.102) \\
N=380\end{array}$ & $\begin{array}{l}-0.128 \\
(0.089) \\
N=222\end{array}$ & $\begin{array}{l}-0.040 \\
(0.053) \\
N=572\end{array}$ \\
\hline Year 3 & $\begin{array}{l}0.085 \\
(0.212) \\
N=83\end{array}$ & $\begin{array}{l}-0.201^{* *} \\
(0.087) \\
\mathrm{N}=378\end{array}$ & $\begin{array}{l}-0.084 \\
(0.133) \\
N=300\end{array}$ & $\begin{array}{l}0.295^{* * *} \\
(0.111) \\
\mathrm{N}=275\end{array}$ & $\begin{array}{l}0.033 \\
(0.136) \\
N=149\end{array}$ & $\begin{array}{l}0.085 \\
(0.060) \\
N=451\end{array}$ \\
\hline Year 4 & $\begin{array}{l}0.122 \\
(0.287) \\
N=60\end{array}$ & $\begin{array}{l}-0.278^{* *} \\
(0.110) \\
\mathrm{N}=275\end{array}$ & $\begin{array}{l}-0.229 \\
(0.180) \\
N=228\end{array}$ & $\begin{array}{l}0.218 \\
(0.197) \\
N=209\end{array}$ & $\begin{array}{l}0.217 \\
(0.143) \\
N=114\end{array}$ & $\begin{array}{l}0.056 \\
(0.073) \\
N=341\end{array}$ \\
\hline Year 5 & $\begin{array}{l}0.504^{* *} \\
(0.247) \\
N=34\end{array}$ & $\begin{array}{c}-0.220^{*} \\
(0.127) \\
\mathrm{N}=163\end{array}$ & $\begin{array}{l}-0.339 * \\
(0.177) \\
N=170\end{array}$ & $\begin{array}{l}0.439 * * \\
(0.189) \\
\mathrm{N}=119\end{array}$ & $\begin{array}{l}0.015 \\
(0.193) \\
N=74\end{array}$ & $\begin{array}{l}0.155^{*} \\
(0.087) \\
N=220\end{array}$ \\
\hline
\end{tabular}

Notes: Bootstrapped standard errors in parenthesis, 1 per cent, 5 per cent and 10 per cent levels of significance are indicated by ${ }^{* *},{ }^{* *}$, and ${ }^{*}$ respectively.

bour productivity growth persisted in Denmark, while its negative and significant effect was still present in Belgium. Foreign acquisitions had no significant effect on labour productivity growth in the other countries. Five years after acquisition, labour productivity growth was significantly higher in Austria, Denmark and Sweden while in Belgium and the Netherlands labour productivity growth was significantly lower. In Finland there were no significant effects. Taken together, country-specific estimates suggest that foreign acquisitions led to significantly higher labour productivity growth in Denmark (in the acquisition year, and one, three and five years after acquisition), as well as in Austria and Sweden (five years after acquisition). Labour productivity growth was significantly lower in Belgium (in the acquisition year as well as in the analysed post-acquisition period) and the Netherlands (in the acquisition year, two and five years after the acquisition). In Finland, foreign acquisitions in services had no significant effect on labour productivity growth.

These results are consistent with the findings of a previous study by Gioia and Thomsen (2004) which finds that foreign acquisitions had a positive effect on the productivity of Danish firms although they do not distinguish between the effect on service and manufacturing firms. ${ }^{28}$

\footnotetext{
28 Gioia and Thomsen (2004) use a selection adjustment (inverse Mill's ratio) from a probit model and control for this in the OLS regression to test the level of productivity measured by the Cobb Douglas measure of TFP.
} 
The estimates of the effect of foreign acquisition on labour productivity growth for manufacturing firms are shown in Table 2.

In contrast to service firms, these results suggest that in most cases foreign acquisitions had no significant effect on labour productivity growth across the six analysed small open economies. Foreign acquisitions led to significantly higher labour productivity growth in Finland one year after acquisition while labour productivity growth was significantly lower in Belgium (in the acquisition year and one year after acquisition), in Denmark (three years after acquisition), in Finland (four years after acquisition) and in Sweden (five years after acquisition).

Karpaty $(2007)^{29}$ and Bandick (2011) ${ }^{30}$ found positive effects on firm productivity in manufacturing in Sweden for the level of Törnqvist TFP as well as TFP growth (estimated following Levinsohn and Petrin 2003). In the case of Denmark, Gioia and Thomsen (2004) found that foreign acquisition had a positive effect on the labour productivity of Danish firms. However, they do not distinguish between the effects on service and manufacturing firms. Finally,

\begin{tabular}{|c|c|c|c|c|c|c|}
\hline \multirow{2}{*}{$\begin{array}{l}\text { Table } 2 \\
\text { Country }\end{array}$} & \multicolumn{6}{|c|}{$\begin{array}{l}\text { The effect of foreign mergers and acquisitions on labour productivity } \\
\text { growth - manufacturing firms }\end{array}$} \\
\hline & Austria & Belgium & Netherlands & Denmark & Finland & Sweden \\
\hline \multirow[t]{3}{*}{ Year 0} & 0.098 & $-0.275^{* *}$ & 0.110 & -0.141 & 0.094 & 0.047 \\
\hline & $(0.254)$ & $(0.111)$ & $(0.151)$ & $(0.130)$ & (0.089) & $(0.053)$ \\
\hline & $\mathrm{N}=81$ & $\mathrm{~N}=178$ & $N=250$ & $N=247$ & $N=159$ & $\mathrm{~N}=349$ \\
\hline \multirow[t]{3}{*}{ Year 1} & 0.002 & $-0.440^{* * *}$ & -0.098 & 0.036 & $0.235^{* *}$ & 0.046 \\
\hline & $(0.212)$ & $(0.121)$ & $(0.156)$ & $(0.136)$ & $(0.095)$ & $(0.060)$ \\
\hline & $\mathrm{N}=68$ & $N=161$ & $N=229$ & $\mathrm{~N}=221$ & $\mathrm{~N}=144$ & $N=321$ \\
\hline \multirow[t]{3}{*}{ Year 2} & -0.032 & -0.092 & 0.043 & -0.225 & -0.080 & -0.086 \\
\hline & $(0.323)$ & $(0.161)$ & $(0.183)$ & $(0.141)$ & $(0.106)$ & $(0.072)$ \\
\hline & $\mathrm{N}=50$ & $\mathrm{~N}=125$ & $\mathrm{~N}=182$ & $N=158$ & $\mathrm{~N}=118$ & $\mathrm{~N}=258$ \\
\hline \multirow[t]{3}{*}{ Year 3} & 0.008 & -0.228 & 0.062 & $-0.313^{* *}$ & -0.007 & -0.102 \\
\hline & $(0.383)$ & $(0.147)$ & $(0.216)$ & $(0.142)$ & $(0.158)$ & $(0.068)$ \\
\hline & $\mathrm{N}=37$ & $\mathrm{~N}=106$ & $\mathrm{~N}=142$ & $\mathrm{~N}=128$ & $N=76$ & $\mathrm{~N}=197$ \\
\hline \multirow[t]{3}{*}{ Year 4} & 0.432 & -0.104 & 0.183 & -0.088 & $-0.431^{* * *}$ & -0.023 \\
\hline & (0.399) & $(0.214)$ & $(0.318)$ & $(0.232)$ & $(0.163)$ & $(0.103)$ \\
\hline & $\mathrm{N}=15$ & $\mathrm{~N}=75$ & $\mathrm{~N}=82$ & $\mathrm{~N}=82$ & $\mathrm{~N}=54$ & $\mathrm{~N}=106$ \\
\hline \multirow[t]{3}{*}{ Year 5} & 0.060 & -0.624 & -0.534 & -0.283 & -0.266 & $-0.243^{* *}$ \\
\hline & $(0.499)$ & $(0.457)$ & $(0.391)$ & $(0.231)$ & $(0.207)$ & $(0.111)$ \\
\hline & $\mathrm{N}=5$ & $\mathrm{~N}=23$ & $\mathrm{~N}=62$ & $\mathrm{~N}=62$ & $\mathrm{~N}=38$ & $\mathrm{~N}=79$ \\
\hline
\end{tabular}

Notes: Bootstrapped standard errors in parenthesis, 1 per cent, 5 per cent and 10 per cent levels of significance are indicated by ${ }^{* * *},{ }^{* *}$, and ${ }^{*}$ respectively.

29 Both Karpaty (2007) use a propensity score matching and difference-in-difference methodology to test the level effect.

30 Bandick (2011) use a propensity score matching and difference-in-difference methodology to explore the growth effect. 
Ilmakunnas and Maliranta (2004) found that foreign acquisition increased the TFP level in Finnish manufacturing firms. ${ }^{31}$

The estimates of the effects of foreign acquisitions on employment growth in service firms are shown in Table 3.

Overall, these estimates indicate that, in the six analysed small open economies, foreign acquisitions led to significantly higher employment growth particularly in the first post-acquisition year. Foreign acquisitions led to significantly higher employment growth in the acquisition year in Austria and Belgium, one year after acquisition in all six countries with the exceptions of Austria and Sweden, two years after acquisition in Denmark and Finland and four years after acquisition in Belgium and Denmark. Five years after acquisition employment growth was significantly higher in the Netherlands and significantly lower in Austria and Sweden. Lehto and Böckerman $(2008)^{32}$ examined service industries and found mixed evidence for the level

\begin{tabular}{lllllll} 
Table 3 & \multicolumn{6}{c}{ The effect of foreign mergers and acquisitions on employment growth - } \\
service firms \\
Country & Austria & Belgium & Netherlands & Denmark & Finland & Sweden \\
Year 0 & $0.275^{*}$ & $0.148^{* *}$ & 0.073 & 0.125 & 0.125 & -0.015 \\
& $(0.162)$ & $(0.060)$ & $(0.090)$ & $(0.108)$ & $(0.078)$ & $(0.050)$ \\
& $\mathrm{N}=191$ & $\mathrm{~N}=731$ & $\mathrm{~N}=643$ & $\mathrm{~N}=500$ & $\mathrm{~N}=325$ & $\mathrm{~N}=767$ \\
Year 1 & 0.175 & $0.178^{* * *}$ & $0.213^{* *}$ & $0.245^{* *}$ & $0.412^{* * *}$ & -0.053 \\
& $(0.146)$ & $(0.067)$ & $(0.103)$ & $(0.101)$ & $(0.097)$ & $(0.054)$ \\
& $\mathrm{N}=186$ & $\mathrm{~N}=651$ & $\mathrm{~N}=552$ & $\mathrm{~N}=481$ & $\mathrm{~N}=287$ & $\mathrm{~N}=703$ \\
& & & & & & \\
Year 2 & 0.046 & 0.011 & 0.132 & $0.402^{* * *}$ & $0.299^{* * *}$ & 0.060 \\
& $(0.182)$ & $(0.077)$ & $(0.096)$ & $(0.122)$ & $(0.111)$ & $(0.059)$ \\
& $\mathrm{N}=139$ & $\mathrm{~N}=523$ & $\mathrm{~N}=449$ & $\mathrm{~N}=380$ & $\mathrm{~N}=222$ & $\mathrm{~N}=572$ \\
Year 3 & -0.094 & 0.059 & 0.214 & 0.022 & 0.149 & -0.043 \\
& $(0.257)$ & $(0.098)$ & $(0.146)$ & $(0.163)$ & $(0.107)$ & $(0.079)$ \\
& $\mathrm{N}=83$ & $\mathrm{~N}=378$ & $\mathrm{~N}=300$ & $\mathrm{~N}=275$ & $\mathrm{~N}=149$ & $\mathrm{~N}=451$ \\
& & & & & & \\
Year 4 & -0.361 & $0.368^{* * *}$ & 0.290 & $0.551^{* * *}$ & 0.126 & 0.025 \\
& $(0.332)$ & $(0.121)$ & $(0.183)$ & $(0.184)$ & $(0.146)$ & $(0.094)$ \\
& $\mathrm{N}=60$ & $\mathrm{~N}=275$ & $\mathrm{~N}=228$ & $\mathrm{~N}=209$ & $\mathrm{~N}=114$ & $\mathrm{~N}=341$ \\
& & & & & & \\
Year 5 & $-0.731^{*}$ & 0.171 & $0.311^{*}$ & 0.465 & -0.141 & $-0.257^{* *}$ \\
& $(0.376)$ & $(0.173)$ & $(0.169)$ & $(0.294)$ & $(0.185)$ & $(0.105)$ \\
& $\mathrm{N}=34$ & $\mathrm{~N}=163$ & $\mathrm{~N}=170$ & $\mathrm{~N}=119$ & $\mathrm{~N}=74$ & $\mathrm{~N}=220$ \\
\hline
\end{tabular}

Notes: Bootstrapped standard errors in parenthesis, 1 per cent, 5 per cent and 10 per cent levels of significance are indicated by ${ }^{* * *},{ }^{* *}$, and ${ }^{*}$ respectively.

\footnotetext{
$31 \quad$ Ilmakunnas and Mariranta (2004) use a propensity score matching and difference-in-difference methodology to examine the level effect.

32 Lehto and Böckerman (2008) use propensity score matching and difference-in-difference estimators for level effects.
} 
effect of foreign acquisition on service firms in Finland with declines in construction and other services, however no effect in trade, hotels and restaurants.

Table 4 shows the estimates of the effects of foreign acquisition on employment growth in manufacturing.

These estimates suggest that in many cases, albeit in less cases than service firms, foreign acquisitions led to significantly higher employment growth in Belgium (in the acquisition year and four years after acquistion), in Denmark (two, three and four years after acquisition). Foreign acquisitions led to lower employment growth in Finland (in the acquisition year and one year after acquisition) and in Sweden (three and five years after acquisition). In Austria and the Netherlands foreign acquisition of manufacturing firms had no significant effects on employment growth. These results are in line with the findings of Bellak, Pfaffermayr and Wild (2006)..$^{33}$ The estimates for Finland are in line with the findings of Lehto and Böckerman (2008). In the case of Sweden, Bandick and Hansson (2009) find that skilled employment increased following acquisition for non-Swedish MNEs with no statistically significant effect for

\begin{tabular}{lllllll} 
Table 4 & \multicolumn{6}{c}{ The effect of foreign mergers and acquisitions on employment growth - } \\
manufacturing firms & & & \\
Country & Austria & Belgium & Netherlands & Denmark & Finland & Sweden \\
Year 0 & 0.191 & $0.211^{*}$ & 0.126 & 0.031 & $-0.245^{* *}$ & -0.065 \\
& $(0.318)$ & $(0.112)$ & $(0.169)$ & $(0.161)$ & $(0.121)$ & $(0.073)$ \\
& $\mathrm{N}=81$ & $\mathrm{~N}=178$ & $\mathrm{~N}=250$ & $\mathrm{~N}=247$ & $\mathrm{~N}=159$ & $\mathrm{~N}=349$ \\
Year 1 & -0.02 & 0.139 & 0.111 & 0.21 & $-0.256^{*}$ & 0.063 \\
& $(0.232)$ & $(0.125)$ & $(0.168)$ & $(0.179)$ & $(0.136)$ & $(0.074)$ \\
& $\mathrm{N}=68$ & $\mathrm{~N}=161$ & $\mathrm{~N}=229$ & $\mathrm{~N}=221$ & $\mathrm{~N}=144$ & $\mathrm{~N}=321$ \\
Year 2 & 0.413 & 0.240 & 0.034 & $0.378^{*}$ & -0.075 & -0.134 \\
& $(0.345)$ & $(0.161)$ & $(0.176)$ & $(0.210)$ & $(0.157)$ & $(0.090)$ \\
& $\mathrm{N}=50$ & $\mathrm{~N}=125$ & $\mathrm{~N}=182$ & $\mathrm{~N}=158$ & $\mathrm{~N}=118$ & $\mathrm{~N}=258$ \\
Year 3 & 0.387 & 0.109 & 0.138 & $0.572^{* *}$ & 0.046 & $-0.190^{*}$ \\
& $(0.37)$ & $(0.159)$ & $(0.223)$ & $(0.242)$ & $(0.209)$ & $(0.098)$ \\
& $\mathrm{N}=37$ & $\mathrm{~N}=106$ & $\mathrm{~N}=142$ & $\mathrm{~N}=128$ & $\mathrm{~N}=76$ & $\mathrm{~N}=197$ \\
& & & & & \\
Year 4 & 0.343 & $0.564^{* *}$ & -0.034 & $1.151^{* * *}$ & -0.260 & -0.089 \\
& $(0.583)$ & $(0.232)$ & $(0.294)$ & $(0.363)$ & $(0.171)$ & $(0.125)$ \\
& $\mathrm{N}=15$ & $\mathrm{~N}=75$ & $\mathrm{~N}=82$ & $\mathrm{~N}=82$ & $\mathrm{~N}=54$ & $\mathrm{~N}=106$ \\
& & & & & & \\
Year 5 & -0.855 & 0.503 & 0.354 & 0.020 & -0.292 & $-0.230^{*}$ \\
& $(2.236)$ & $(0.403)$ & $(0.288)$ & $(0.339)$ & $(0.306)$ & $(0.126)$ \\
& $\mathrm{N}=5$ & $\mathrm{~N}=23$ & $\mathrm{~N}=62$ & $\mathrm{~N}=62$ & $\mathrm{~N}=38$ & $\mathrm{~N}=79$ \\
\hline
\end{tabular}

Notes: Bootstrapped standard errors in parenthesis, 1 per cent, 5 per cent and 10 per cent levels of significance are indicated by ******, and * respectively.

\footnotetext{
33 Bellak, Pfaffermayr and Wild (2007) use propensity score matching and difference-in-difference estimators to examine the growth effect in Austrian manufacturing firms.
} 
Swedish MNEs. Furthermore, Bandick and Görg (2010) $)^{34}$ find positive employment growth in exporting firms and Swedish MNEs in vertical acquisitions only, while Bandick and Karpaty $(2011)^{35}$ find positive employment growth in non-MNEs with no growth effect for Swedish MNE's.

\section{$7 \quad$ Conclusions}

We analysed the causal link between foreign investment and firm performance in six small open economies in the European Union. Specifically, we used micro data from Austria, Belgium, Denmark, Finland, the Netherlands and Sweden over the period 2001-2009 and propensity score matching combined with difference-in-difference estimators to identify the causal effect of foreign investment on labour productivity and employment growth. While much of the previous literature considers foreign investment in manufacturing firms, we examine both service and manufacturing firms. To disentangle causality from correlation effects, we analyse the effects of foreign mergers and acquisitions on firm performance.

Our evidence indicates that foreign investors tend to acquire larger firms in manufacturing as well as services. Other characteristics of acquired firms differ across countries and between manufacturing and services.

Taken together, our estimates suggest that foreign acquisitions had stronger effects on firm performance in services than in manufacturing. Overall, no general pattern emerges with respect to the effects of foreign investment on firm performance across the analysed six small open economies. Foreign acquisitions in services led to higher labour productivity and higher employment growth in Denmark, lower productivity growth and higher employment growth in Belgium and the Netherlands. Foreign acquisitions in services in Finland had no significant effect on labour productivity growth but they led to higher employment growth two and three years after acquisitions. In Austria and Sweden, foreign acquisitions led to higher productivity growth and lower employment growth five years after acquisition.

In the case of manufacturing, it appears that foreign acquisitions led to lower labour productivity growth and higher employment growth in Belgium and Denmark. In Finland and Sweden, in most cases, foreign acquisitions led to lower productivity growth and lower employment growth, while in Austria and the Netherlands, there were no significant changes in labour productivity and employment growth in the post-acquisition period.

Finally, our analysis suggests that the effects of foreign investment on firm performance are likely to be conditioned by economic, social and institutional country specific characteristics. Further research linking these results to relevant country characteristics would contribute to a better understanding of the effects of foreign investment on firm performance.

Bandick and Görg (2010) use propensity score matching, difference-in-differences and IV to examine the growth effect.

35 Bandick and Karpaty (2011) use propensity score matching, difference-in-differences and IV to test the growth effect. 


\section{Appendix A Literature review}

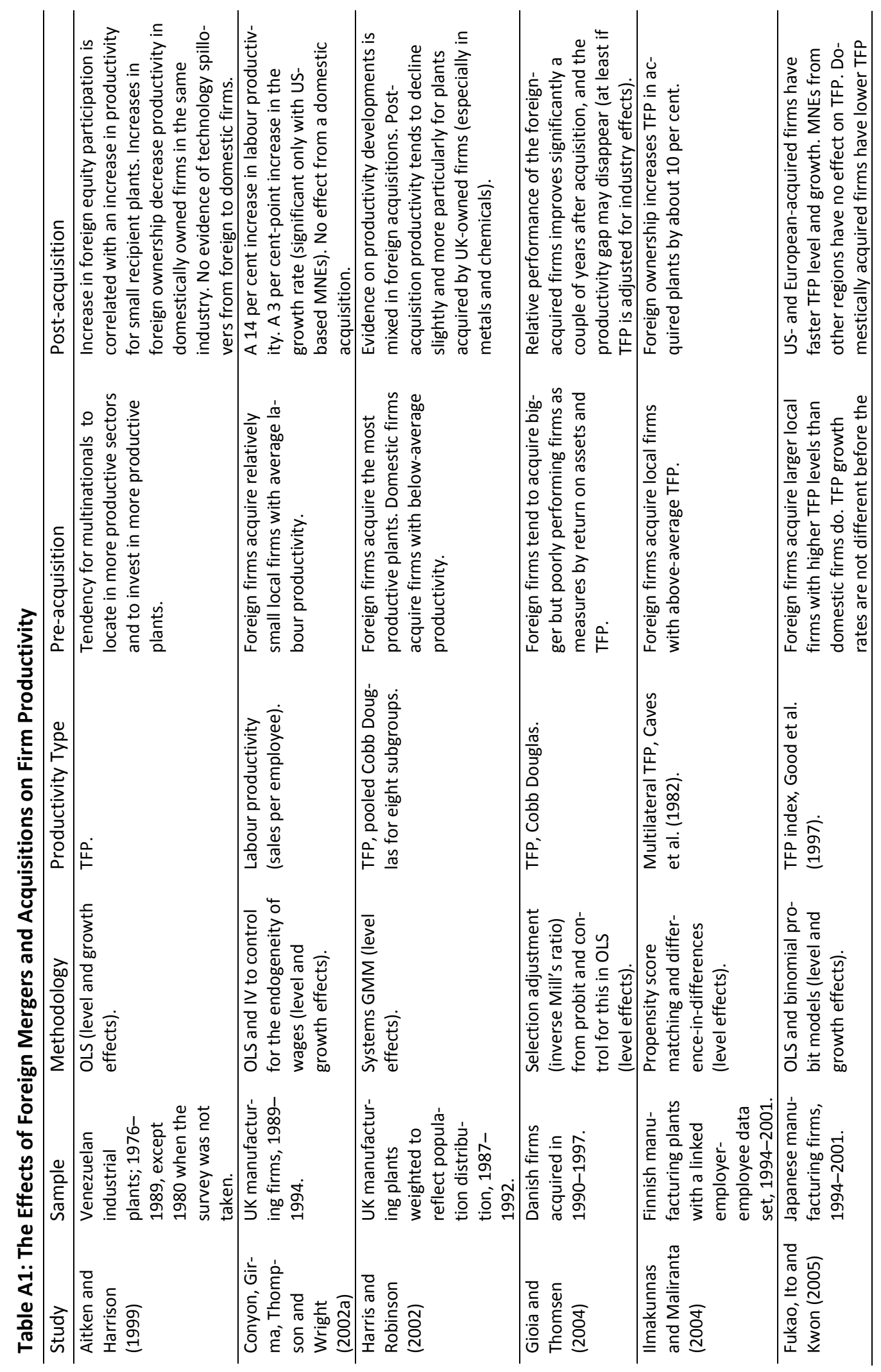




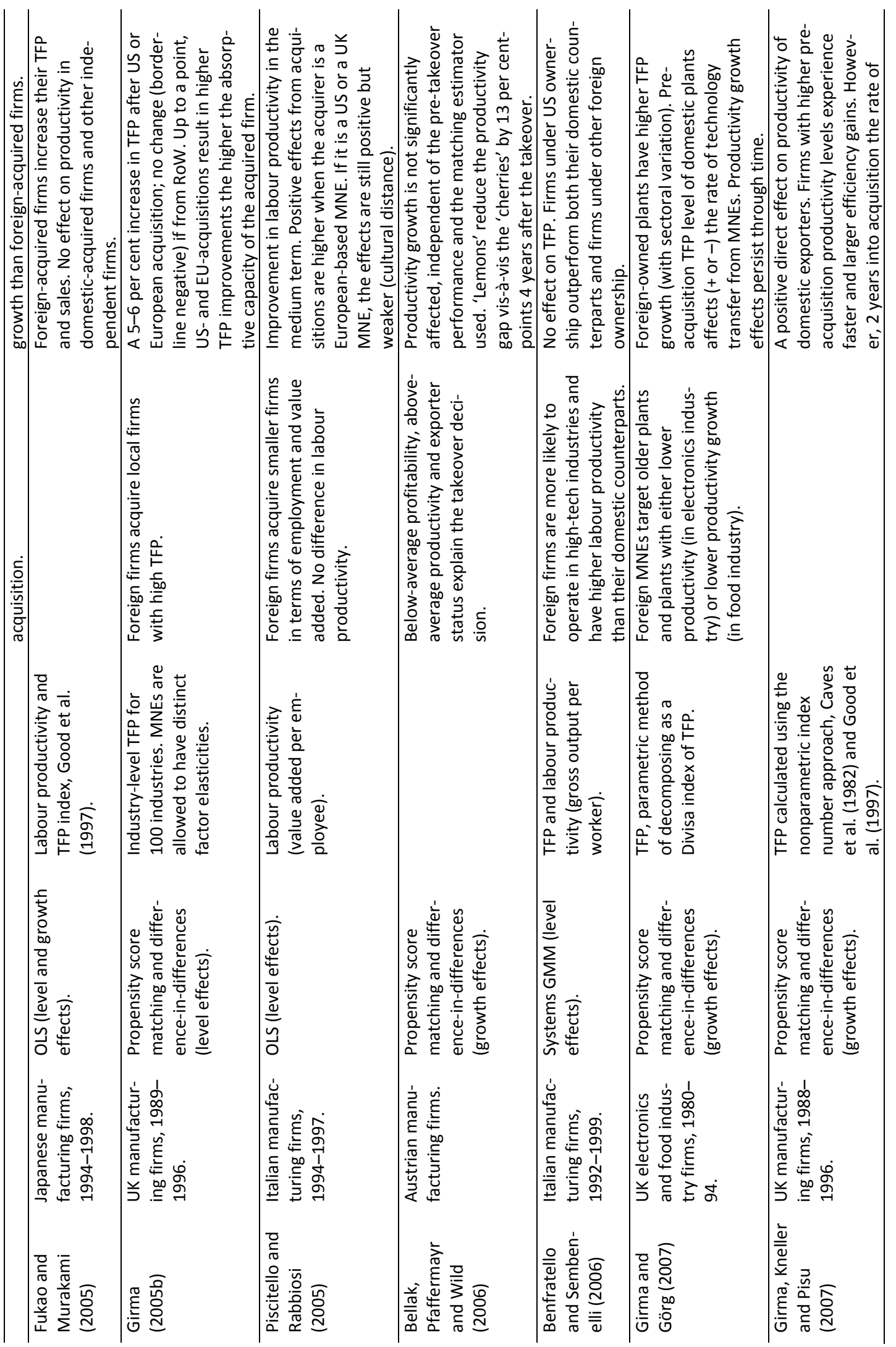




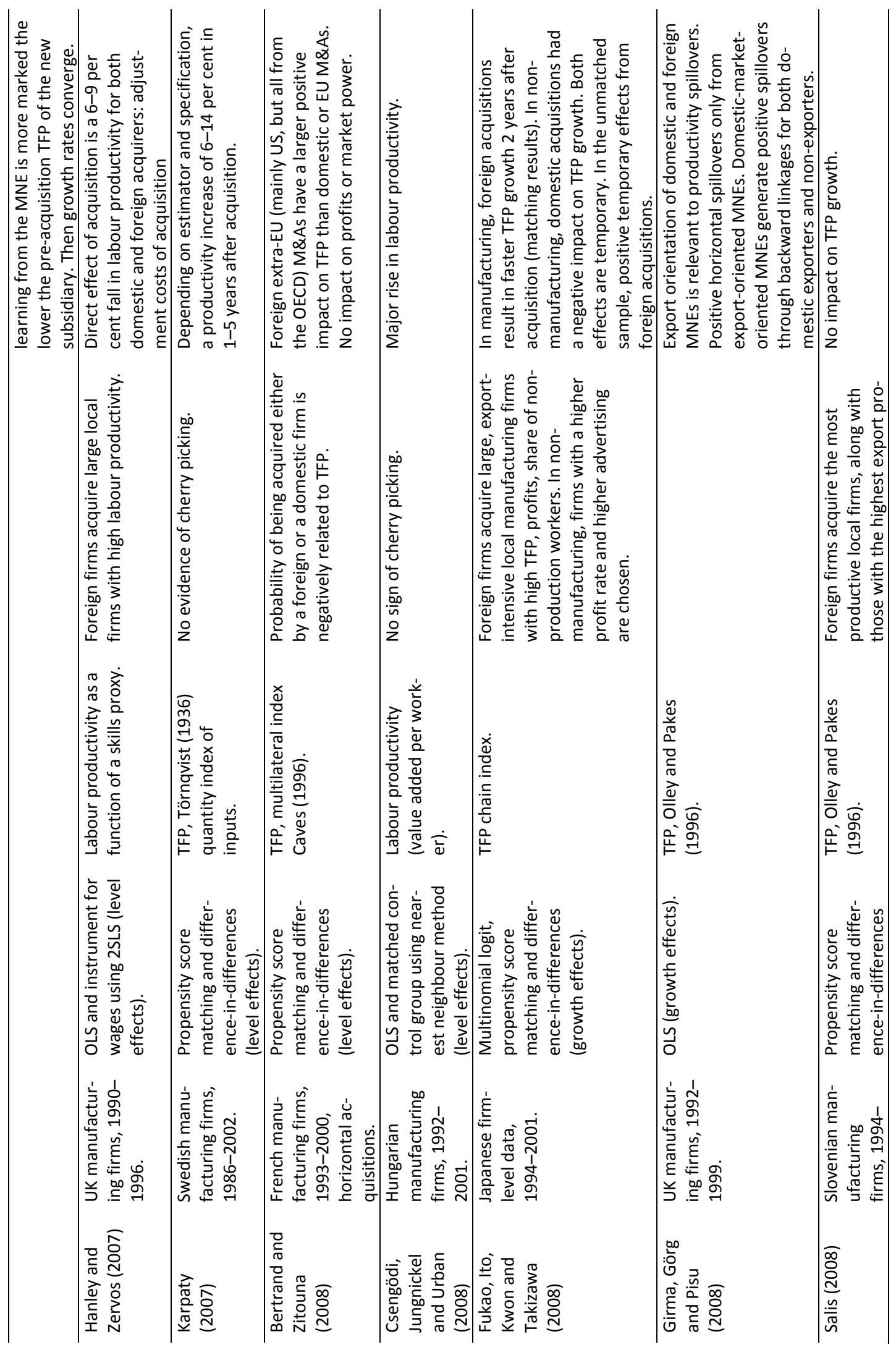




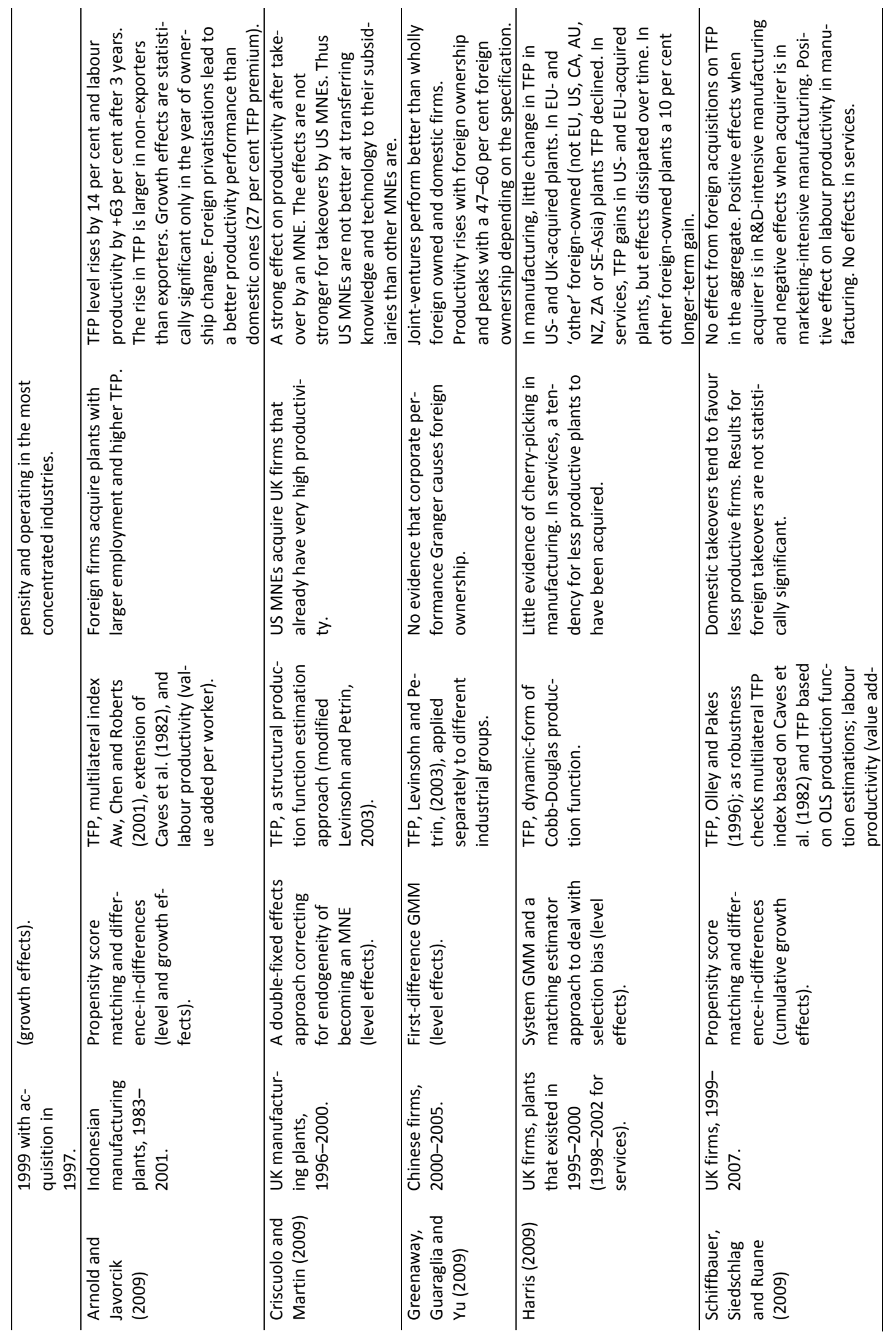




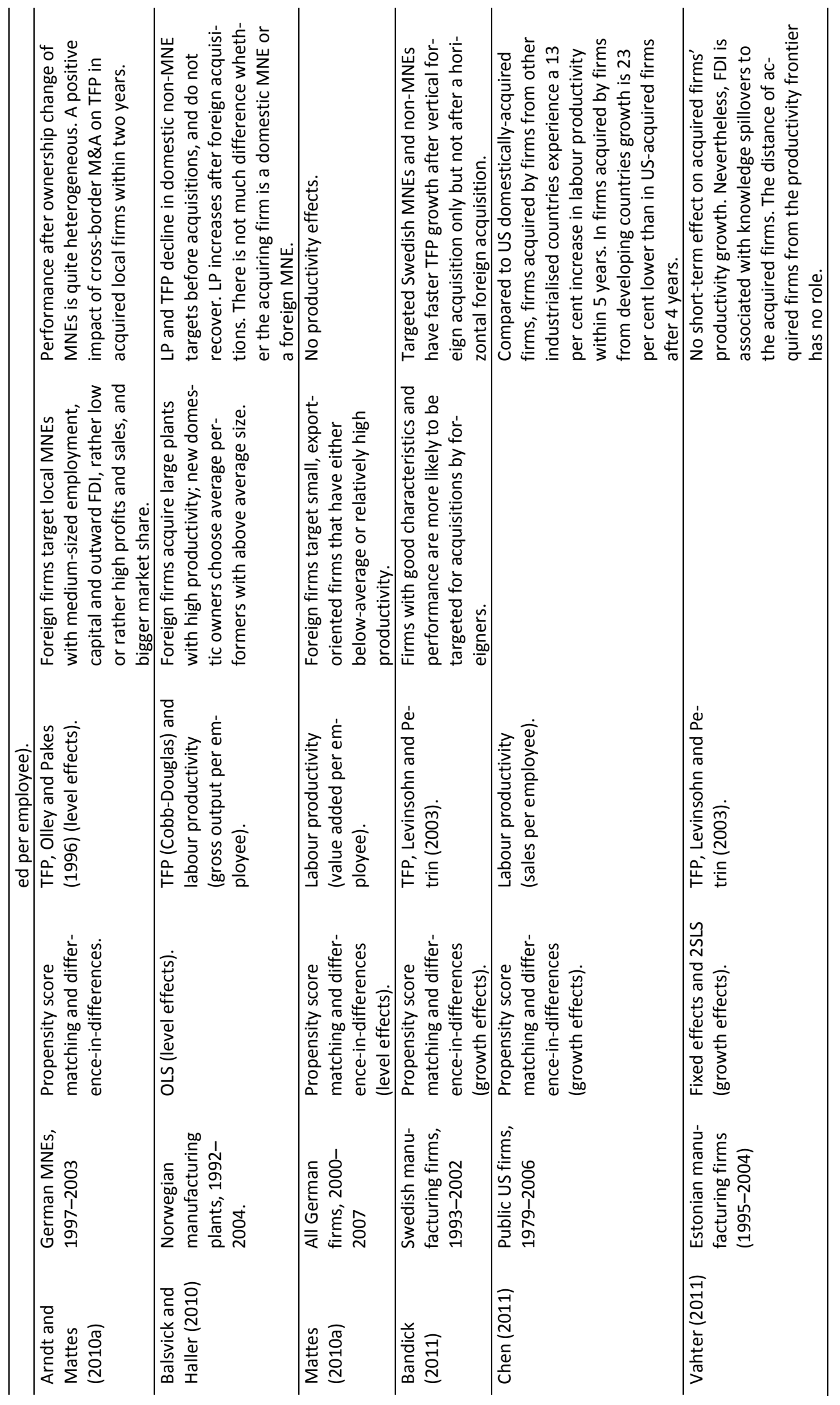




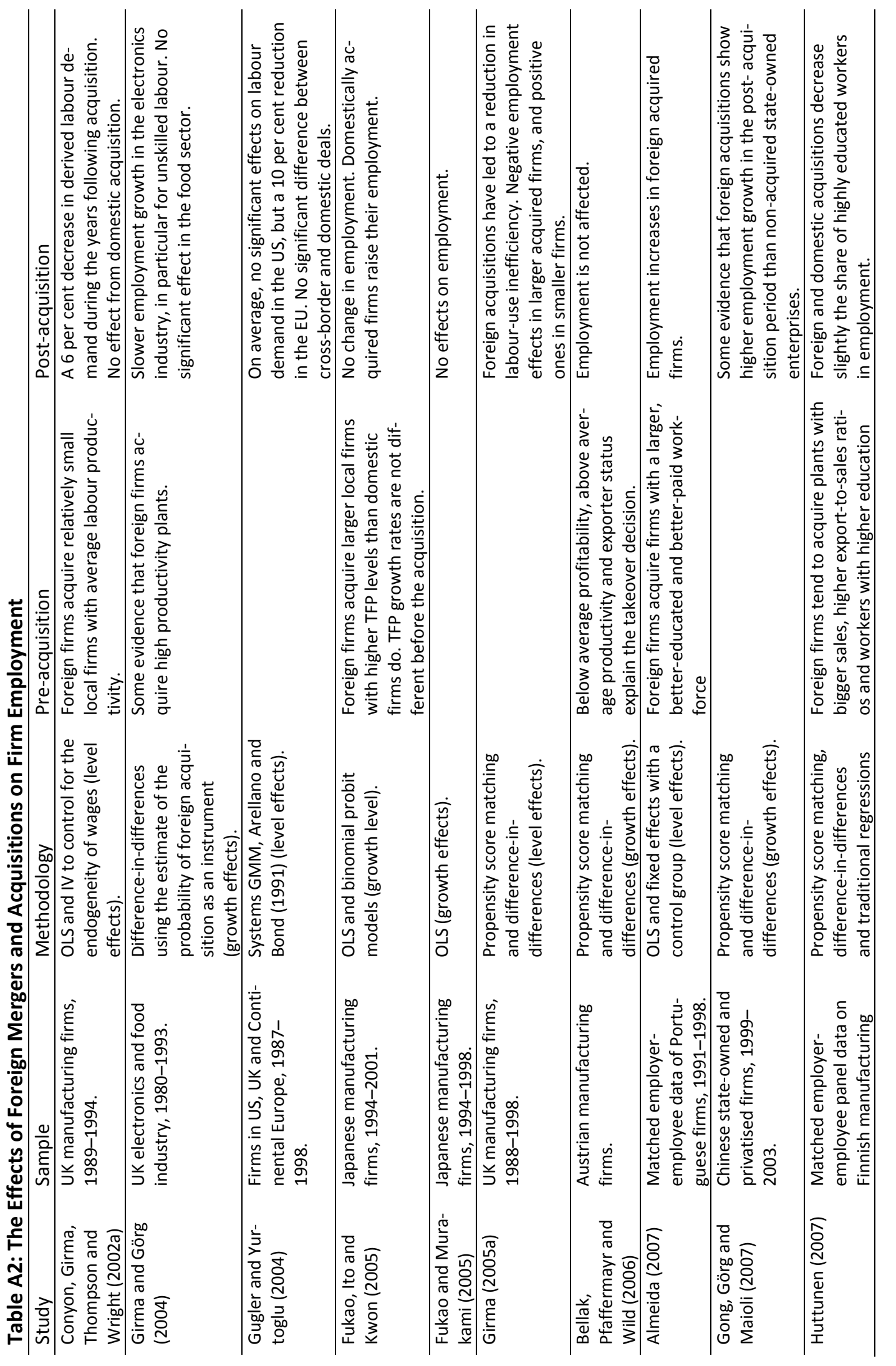




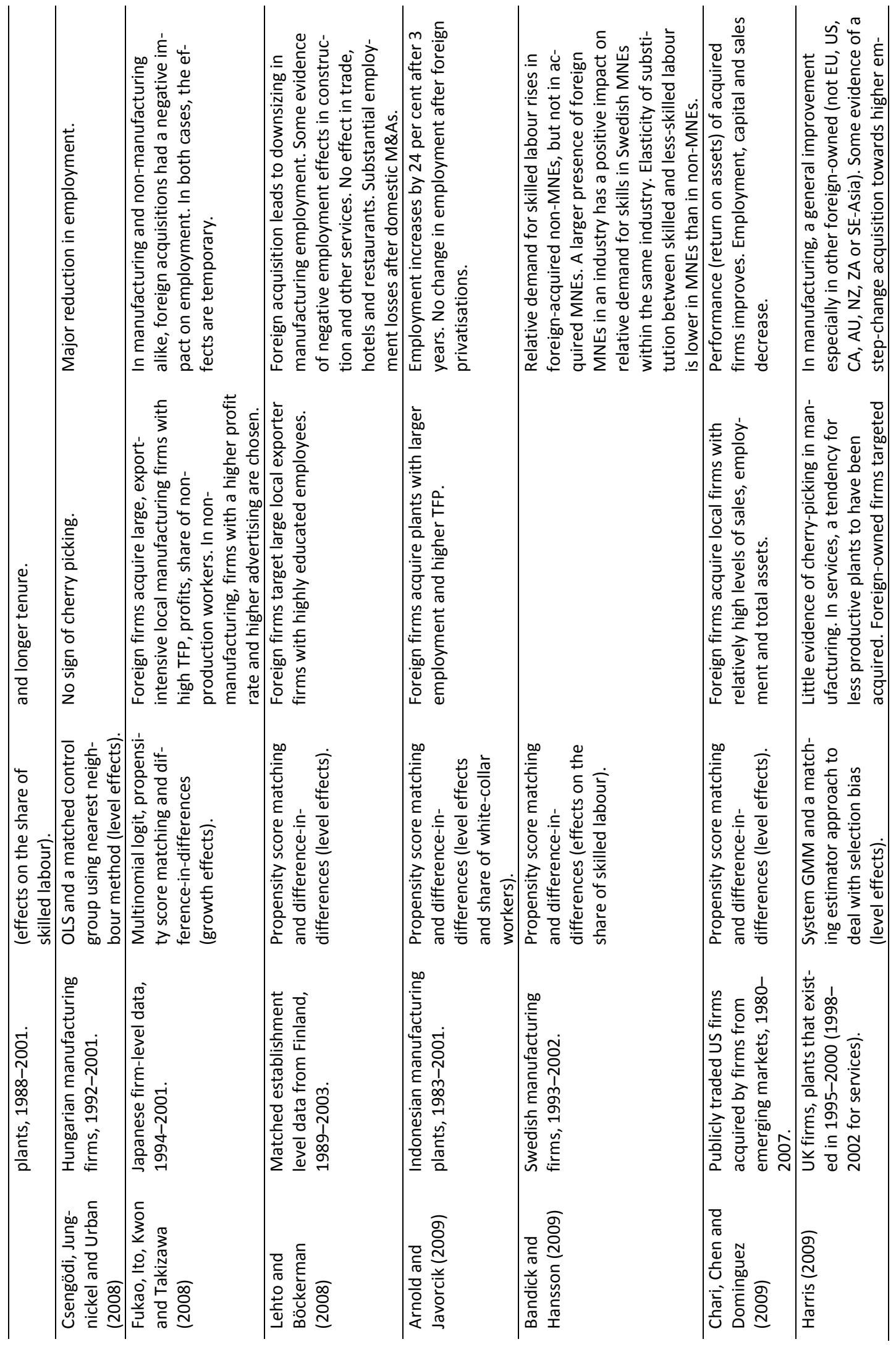




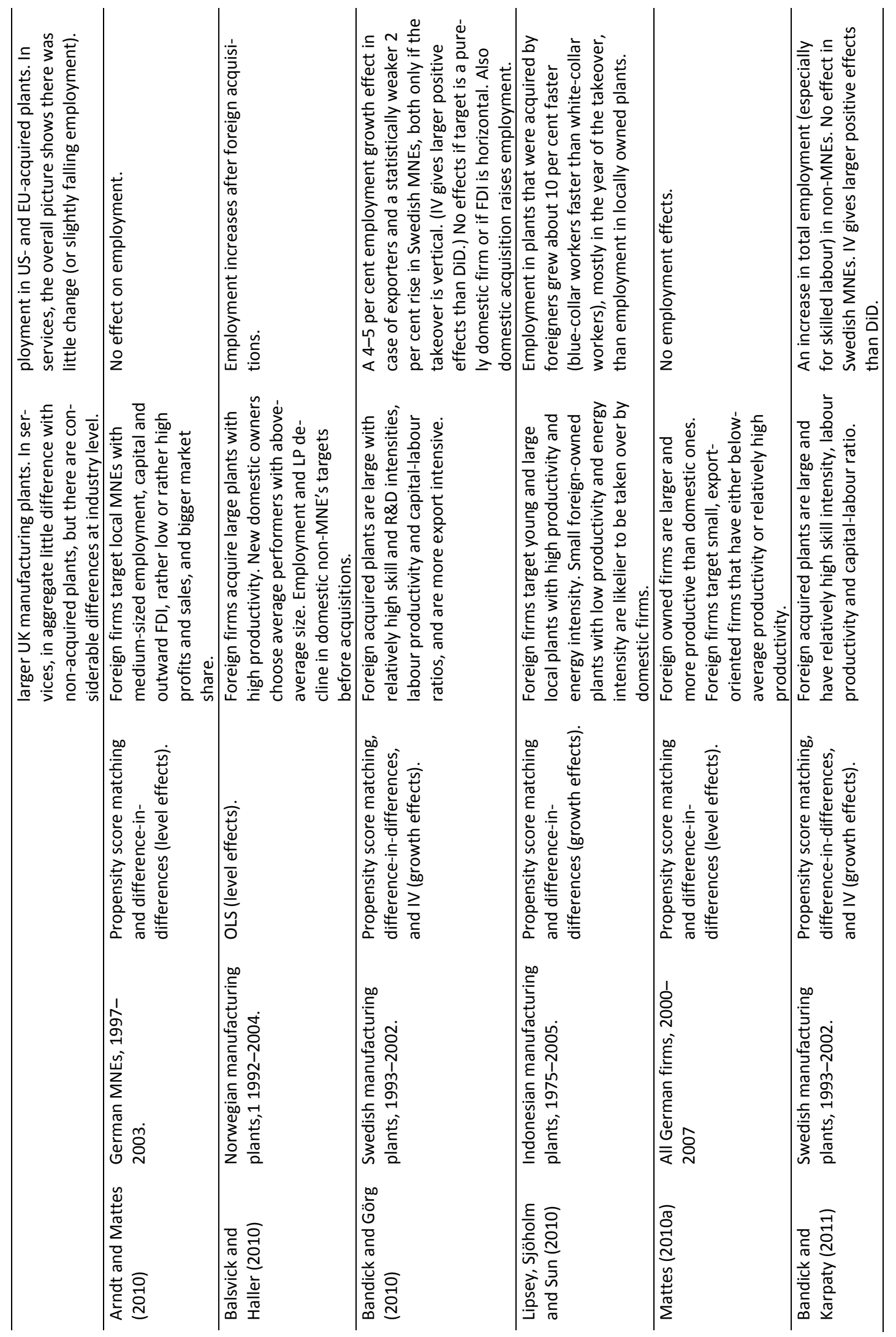




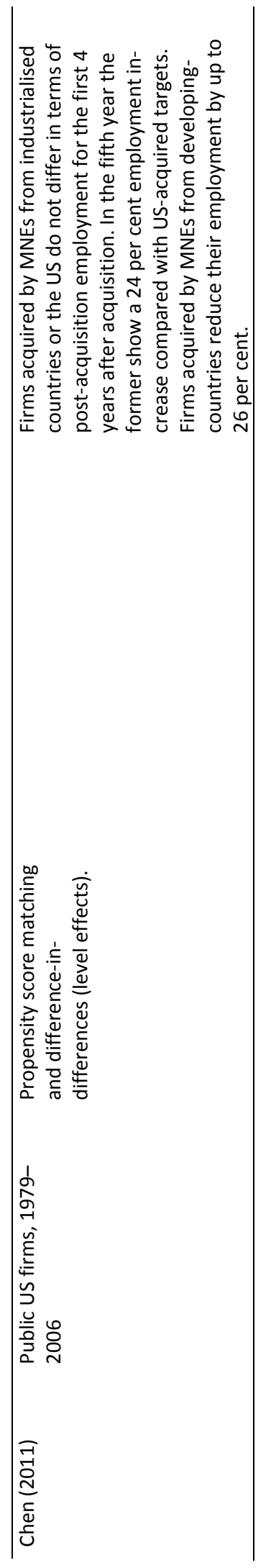




\section{Appendix B Data imputation methodology}

Missing values in the Amadeus dataset impose significant difficulty on the econometric analysis. For example, original data of Finnish firms only offer 24 matched targets for the evaluation of the effect of foreign acquisition in the services sector.

To deal with this issue, we apply the weighted hotdeck multiple imputation method (Mander and Clayton 2003) to impute data. The weighted hotdeck method replaces missing values with sampled observations with complete data. Observations with missing values and complete data are stratified using the same variables that indicate the characteristics of observations. Sampling is made within strata so as to achieve better matching. Weighted hotdeck improves the imputation method by incorporating the missingness of the data in the sampling. Firstly, it fits a logistic model with independent variables that explain the occurrence of having missing values. After that, the propensity score of having missing values is predicted and it serves as weight in the last step. Finally, a weighted sampling of observations with complete data is performed to create data points for the observations with missing values. The weighted hotdeck relies on the assumption that missing values are either missing completely at random (MCAR) or missing at random (MAR).

The weighted hotdeck method has the following advantages over other imputation methods (Rubin 1987, Schafer 1997). 1) It only requires very few distributional assumptions of the data (Mander and Clayton 2003). 2) It does not rely on parametric models to fit the missing values, therefore it is less sensitive to model misspecification (Andridge and Little 2010). 3) Only plausible values will be imputed (Andridge and Little 2010).

We use a Stata routine -whotdeck- (Mander 2003) to impute the following variables with missing values: turnover, employment, fixed tangible assets, depreciation, value added, debts and fixed assets. The explanatory variables of the logistic model of missingness are 3-digit industry dummies, foreign ownership dummy, size class, year dummies and a set of foreign acquisition and domestic acquisition indicators interacted with thresholds. Five sets of imputed data are independently generated and they form a multiple imputation scheme. The multiple imputation method treats the data generation process as stochastic rather than deterministic, thus accounting for the variation across datasets. Doing imputation five times is considered sufficient by the authors of -whotdeck-.

With imputed datasets, we are able to evaluate the effect of foreign acquisition in services sector of Finland for up to 65.2 (average across the five datasets) matched targets.

Each of the imputed datasets will be analysed independently using the same econometric model, e.g. the Probit model of the propensity of being acquired by foreign or domestic acquirers. However, the estimated parameters from each datasets can be combined using Rubin's rule (Rubin 1987) in order to draw inference for the overall data.

Rubin (1987) proposes formula to combine repeated-imputation summary statistics. Let $\vartheta=\left(\hat{\theta}_{1}, \hat{\theta}_{2}, \ldots, \hat{\theta}_{m}\right)$ be the estimate of interest from $m$ imputed datasets. The mean of $\theta$ is given as follows:

$$
\bar{\vartheta}_{m}=\sum_{l=1}^{m} \hat{\theta}_{l} / m
$$


The average of variance of the dataset estimates is $\bar{U}_{m}=\sum_{l=1}^{m} \operatorname{Var}\left(\hat{\theta}_{l}\right) / m$.

The average of the variances between the $\mathrm{m}$ dataset estimates is $B_{m}=\sum_{l=1}^{m}\left(\hat{\theta}_{l}-\bar{\theta}_{l}\right)^{2} /(m-1)$.

The total variance is defined as $\bar{U}_{m}+\left(1+m^{-1}\right) B_{m}$. 


\section{Appendix C Summary statistics}

\begin{tabular}{|c|c|c|c|c|c|c|}
\hline Table C1 & mmary stat & stics of for & eign-acquire & d firms - ser & ices & \\
\hline Country & Austria & Belgium & Netherlands & Denmark & Finland & Sweden \\
\hline Deflated turnover & $\begin{array}{l}90821.1 \\
(216923.5) \\
\mathrm{N}=2300\end{array}$ & $\begin{array}{l}37339.2 \\
(168961.2) \\
N=9950\end{array}$ & $\begin{array}{l}107146.8 \\
(566103.7) \\
N=8100\end{array}$ & $\begin{array}{l}49207.1 \\
(177171.8) \\
N=5800\end{array}$ & $\begin{array}{l}18544.2 \\
(99130.1) \\
N=4600\end{array}$ & $\begin{array}{l}10225.0 \\
(33186.5) \\
N=8550\end{array}$ \\
\hline $\begin{array}{l}\text { Deflated value } \\
\text { added }\end{array}$ & $\begin{array}{l}25701.8 \\
(93280.4) \\
N=2256\end{array}$ & $\begin{array}{l}9903.4 \\
(45424.2) \\
N=9689\end{array}$ & $\begin{array}{l}15830.3 \\
(70903.3) \\
N=7839\end{array}$ & - & $\begin{array}{l}3100.2 \\
(12616.1) \\
N=4537\end{array}$ & $\begin{array}{l}3658.5 \\
(15407.0) \\
N=8130\end{array}$ \\
\hline Employment & $\begin{array}{l}280.4 \\
(858.5) \\
N=2300\end{array}$ & $\begin{array}{l}119.0 \\
(326.8) \\
N=9950\end{array}$ & $\begin{array}{l}139.8 \\
(370.8) \\
N=8100\end{array}$ & $\begin{array}{l}140.1 \\
(477.3) \\
N=5706\end{array}$ & $\begin{array}{l}57.7 \\
(254.1) \\
N=4600\end{array}$ & $\begin{array}{l}54.5 \\
(262.4) \\
N=8467\end{array}$ \\
\hline $\begin{array}{l}\text { Deflated turnover } \\
\text { per employee }\end{array}$ & $\begin{array}{l}1334.6 \\
(11055.2) \\
N=2300\end{array}$ & $\begin{array}{l}1013.6 \\
(4648.6) \\
N=9950\end{array}$ & $\begin{array}{l}2704.2 \\
(18362.6) \\
N=8100\end{array}$ & $\begin{array}{l}1727.8 \\
(19878.0) \\
N=5706\end{array}$ & $\begin{array}{l}346.9 \\
(903.0) \\
N=4600\end{array}$ & $\begin{array}{l}345.1 \\
(801.6) \\
N=8467\end{array}$ \\
\hline $\begin{array}{l}\text { Deflated value } \\
\text { added per } \\
\text { employee }\end{array}$ & $\begin{array}{l}393.0 \\
(4518.9) \\
N=2256\end{array}$ & $\begin{array}{l}274.7 \\
(6221.4) \\
N=9689\end{array}$ & $\begin{array}{l}277.7 \\
(1627.2) \\
N=7839\end{array}$ & - & $\begin{array}{l}71.6 \\
(106.6) \\
N=4537\end{array}$ & $\begin{array}{l}107.4 \\
(291.1) \\
N=8051\end{array}$ \\
\hline Age & $\begin{array}{l}18.8 \\
(23.0) \\
N=1925\end{array}$ & $\begin{array}{l}19.5 \\
(17.4) \\
N=8555\end{array}$ & $\begin{array}{l}17.8 \\
(17.3) \\
N=6840\end{array}$ & $\begin{array}{l}16.8 \\
(17.7) \\
N=5040\end{array}$ & $\begin{array}{l}12.7 \\
(12.4) \\
N=4012\end{array}$ & $\begin{array}{l}17.7 \\
(19.0) \\
N=7325\end{array}$ \\
\hline Debt/fixed assets & $\begin{array}{l}2.9 \\
(17.1) \\
N=2299\end{array}$ & $\begin{array}{l}21.2 \\
(594.3) \\
N=9935\end{array}$ & $\begin{array}{l}57.6 \\
(825.0) \\
N=8063\end{array}$ & $\begin{array}{l}14.8 \\
(594.6) \\
N=5777\end{array}$ & $\begin{array}{l}6.6 \\
(21.5) \\
N=4590\end{array}$ & $\begin{array}{l}9.8 \\
(36.5) \\
N=8537\end{array}$ \\
\hline $\begin{array}{l}\text { Deflated total } \\
\text { assets per } \\
\text { employee }\end{array}$ & $\begin{array}{l}544.6 \\
(5010.5) \\
N=2293\end{array}$ & $\begin{array}{l}122.0 \\
(1170.0) \\
N=9878\end{array}$ & $\begin{array}{l}266.5 \\
(4278.3) \\
N=7969\end{array}$ & $\begin{array}{l}412.5 \\
(7268.2) \\
N=5620\end{array}$ & $\begin{array}{l}55.0 \\
(604.3) \\
N=4553\end{array}$ & $\begin{array}{l}193.5 \\
(1413.0) \\
N=8380\end{array}$ \\
\hline
\end{tabular}

Notes: The figures shown above are the mean, standard deviation (in parenthesis) and total number of observations (N). Turnover and value added are deflated by a GDP deflator with 2006 as the base year. Foreign acquisition is defined as any ownership stake crossing a threshold of 10 per cent of total shareholding. 


\begin{tabular}{|c|c|c|c|c|c|c|}
\hline \multirow{2}{*}{$\begin{array}{l}\text { Table C2 } \\
\text { Country }\end{array}$} & \multicolumn{6}{|c|}{ Summary statistics of non-acquired firms - services } \\
\hline & Austria & Belgium & Netherlands & Denmark & Finland & Sweden \\
\hline \multirow[t]{2}{*}{ Deflated turnover } & $\begin{array}{l}101592.8 \\
(271747.7)\end{array}$ & $\begin{array}{l}38435.8 \\
(253376.7)\end{array}$ & $\begin{array}{l}101598.2 \\
(518048.2)\end{array}$ & $\begin{array}{l}36616.0 \\
(187574.3)\end{array}$ & $\begin{array}{l}8124.4 \\
(54281.4)\end{array}$ & $\begin{array}{l}6682.9 \\
(65059.4)\end{array}$ \\
\hline & $\mathrm{N}=522500$ & $\mathrm{~N}=916800$ & $N=2225600$ & $\mathrm{~N}=501950$ & $\mathrm{~N}=484050$ & $N=1637900$ \\
\hline \multirow{3}{*}{$\begin{array}{l}\text { Deflated value } \\
\text { added }\end{array}$} & 27435.0 & 8372.8 & 15525.3 & - & 1774.1 & 1728.1 \\
\hline & (91872.8) & $(57305.8)$ & (75510.6) & & $(9154.5)$ & $(29551.2)$ \\
\hline & $\mathrm{N}=513903$ & $\mathrm{~N}=898424$ & $N=2166217$ & & $\mathrm{~N}=479857$ & $N=1601845$ \\
\hline \multirow[t]{3}{*}{ Employment } & 300.8 & 89.1 & 138.7 & 122.5 & 32.8 & 27.7 \\
\hline & $(805.9)$ & (404.6) & $(374.1)$ & (441.7) & $(163.6)$ & $(213.1)$ \\
\hline & $\mathrm{N}=522500$ & $N=916800$ & $N=2225600$ & $\mathrm{~N}=491785$ & $\mathrm{~N}=484050$ & $\mathrm{~N}=1616576$ \\
\hline \multirow{3}{*}{$\begin{array}{l}\text { Deflated turnover } \\
\text { per employee }\end{array}$} & 1369.0 & 1418.7 & 3382.8 & 737.1 & 409.6 & 410.9 \\
\hline & (10049.0) & (8924.6) & (39515.9) & (8961.4) & $(4046.3)$ & (7175.7) \\
\hline & $\mathrm{N}=522500$ & $\mathrm{~N}=916800$ & $\mathrm{~N}=2225600$ & $\mathrm{~N}=491785$ & $\mathrm{~N}=484050$ & $N=1616576$ \\
\hline \multirow{3}{*}{$\begin{array}{l}\text { Deflated value } \\
\text { added per } \\
\text { employee }\end{array}$} & 349.5 & 220.9 & 323.5 & - & 76.9 & 87.1 \\
\hline & (3383.4) & (7210.6) & $(2890.1)$ & & $(270.2)$ & $(587.8)$ \\
\hline & $\mathrm{N}=513903$ & $\mathrm{~N}=898424$ & $N=2166217$ & & $\mathrm{~N}=479857$ & $\mathrm{~N}=1583191$ \\
\hline \multirow[t]{3}{*}{ Age } & 17.6 & 17.4 & 22.7 & 13.1 & 14.5 & 16.4 \\
\hline & $(26.5)$ & $(13.8)$ & $(23.7)$ & (13.6) & (13.5) & $(16.5)$ \\
\hline & $\mathrm{N}=401605$ & $\mathrm{~N}=766910$ & $\mathrm{~N}=1885315$ & $\mathrm{~N}=388460$ & $N=396661$ & $\mathrm{~N}=1263425$ \\
\hline \multirow[t]{3}{*}{ Debt/fixed assets } & 3.1 & 27.5 & 57.3 & 10.7 & 4.7 & 7.2 \\
\hline & $(17.8)$ & (1008.8) & (771.9) & $(327.1)$ & $(36.5)$ & $(54.7)$ \\
\hline & $\mathrm{N}=521589$ & $N=914372$ & $N=2215440$ & $\mathrm{~N}=499157$ & $\mathrm{~N}=483061$ & $N=1630641$ \\
\hline \multirow{3}{*}{$\begin{array}{l}\text { Deflated total } \\
\text { assets per } \\
\text { employee }\end{array}$} & 407.8 & 146.0 & 332.6 & 451.0 & 143.5 & 189.8 \\
\hline & $(3865.1)$ & $(1466.5)$ & $(6274.4)$ & $(6270.7)$ & $(1724.7)$ & $(1426.2)$ \\
\hline & $\mathrm{N}=520494$ & $\mathrm{~N}=907584$ & $N=2190947$ & $\mathrm{~N}=483039$ & $\mathrm{~N}=480166$ & $N=1600755$ \\
\hline
\end{tabular}

Notes: The figures shown above are the mean, standard deviation (in parenthesis) and total number of observations (N). Turnover and value added are deflated by a GDP deflator with 2006 as the base year. Foreign acquisition is defined as any ownership stake crossing a threshold of 10 per cent of total shareholding. 


\begin{tabular}{|c|c|c|c|c|c|c|}
\hline \multicolumn{7}{|c|}{ Summary statistics of all firms - services } \\
\hline Country & Austria & Belgium & Netherlands & Denmark & Finland & Sweden \\
\hline Deflated turnover & $\begin{array}{l}101578.4 \\
(271539.3) \\
N=526700\end{array}$ & $\begin{array}{l}38416.1 \\
(252597.5) \\
N=935750\end{array}$ & $\begin{array}{l}101614.6 \\
(518280.3) \\
N=2250000\end{array}$ & $\begin{array}{l}36721.8 \\
(186744.6) \\
N=513700\end{array}$ & $\begin{array}{l}8266.2 \\
(54540.4) \\
N=504750\end{array}$ & $\begin{array}{l}6717.1 \\
(64870.3) \\
N=1660200\end{array}$ \\
\hline $\begin{array}{l}\text { Deflated value } \\
\text { added }\end{array}$ & $\begin{array}{l}27432.2 \\
(91847.4) \\
N=518034\end{array}$ & $\begin{array}{l}8387.7 \\
(57015.6) \\
N=916882\end{array}$ & $\begin{array}{l}15526.7 \\
(75509.8) \\
N=2189915\end{array}$ & - & $\begin{array}{l}1805.6 \\
(9141.4) \\
N=500365\end{array}$ & $\begin{array}{l}1741.7 \\
(29397.6) \\
N=1623186\end{array}$ \\
\hline Employment & $\begin{array}{l}300.7 \\
(806.8) \\
N=526700\end{array}$ & $\begin{array}{l}89.5 \\
(403.6) \\
N=935750\end{array}$ & $\begin{array}{l}138.7 \\
(374.3) \\
N=2250000\end{array}$ & $\begin{array}{l}122.6 \\
(441.6) \\
N=503342\end{array}$ & $\begin{array}{l}33.5 \\
(164.5) \\
N=504750\end{array}$ & $\begin{array}{l}28.0 \\
(213.3) \\
\mathrm{N}=1638649\end{array}$ \\
\hline $\begin{array}{l}\text { Deflated turnover } \\
\text { per employee }\end{array}$ & $\begin{array}{l}1368.8 \\
(10042.5) \\
N=526700\end{array}$ & $\begin{array}{l}1411.8 \\
(8942.4) \\
\mathrm{N}=935750\end{array}$ & $\begin{array}{l}3379.8 \\
(39438.4) \\
N=2250000\end{array}$ & $\begin{array}{l}749.1 \\
(9138.1) \\
N=503342\end{array}$ & $\begin{array}{l}405.3 \\
(3970.8) \\
N=504750\end{array}$ & $\begin{array}{l}412.9 \\
(7236.8) \\
N=1638649\end{array}$ \\
\hline $\begin{array}{l}\text { Deflated value } \\
\text { added per } \\
\text { employee }\end{array}$ & $\begin{array}{l}349.6 \\
(3384.3) \\
N=518034\end{array}$ & $\begin{array}{l}221.1 \\
(7168.1) \\
N=916882\end{array}$ & $\begin{array}{l}323.2 \\
(2885.4) \\
N=2189915\end{array}$ & - & $\begin{array}{l}76.5 \\
(266.8) \\
N=500365\end{array}$ & $\begin{array}{l}87.5 \\
(593.3) \\
N=1604321\end{array}$ \\
\hline Age & $\begin{array}{l}17.6 \\
(26.5) \\
N=405120\end{array}$ & $\begin{array}{l}17.4 \\
(13.9) \\
N=783355\end{array}$ & $\begin{array}{l}22.7 \\
(23.7) \\
N=1906125\end{array}$ & $\begin{array}{l}13.2 \\
(13.7) \\
N=398345\end{array}$ & $\begin{array}{l}14.5 \\
(13.5) \\
N=414371\end{array}$ & $\begin{array}{l}16.4 \\
(16.5) \\
N=1282580\end{array}$ \\
\hline Debt/fixed assets & $\begin{array}{l}3.1 \\
(17.8) \\
N=525783\end{array}$ & $\begin{array}{l}27.3 \\
(1000.6) \\
N=933275\end{array}$ & $\begin{array}{l}57.3 \\
(772.0) \\
N=2239745\end{array}$ & $\begin{array}{l}10.8 \\
(336.0) \\
N=510864\end{array}$ & $\begin{array}{l}4.7 \\
(36.5) \\
N=503735\end{array}$ & $\begin{array}{l}7.2 \\
(54.5) \\
N=1652845\end{array}$ \\
\hline $\begin{array}{l}\text { Deflated total } \\
\text { assets per } \\
\text { employee }\end{array}$ & $\begin{array}{l}408.8 \\
(3872.3) \\
N=524681\end{array}$ & $\begin{array}{l}145.3 \\
(1458.0) \\
N=926349\end{array}$ & $\begin{array}{l}332.0 \\
(6262.8) \\
N=2214980\end{array}$ & $\begin{array}{l}451.1 \\
(6290.2) \\
N=494405\end{array}$ & $\begin{array}{l}140.7 \\
(1705.8) \\
N=500685\end{array}$ & $\begin{array}{l}190.2 \\
(1443.3) \\
N=1622594\end{array}$ \\
\hline
\end{tabular}

Notes: The figures shown above are the mean, standard deviation (in parenthesis) and total number of observations (N). Turnover and value added are deflated by a GDP deflator with 2006 as the base year. Foreign acquisition is defined as any ownership stake crossing a threshold of 10 per cent of total shareholding. 


\begin{tabular}{|c|c|c|c|c|c|c|}
\hline Table C4 & nary st & tics of fore & eign-acquir & firms - m & ufacturing & \\
\hline Country & Austria & Belgium & Netherlands & Denmark & Finland & Sweden \\
\hline Deflated turnover & $\begin{array}{l}94415.5 \\
(194243.8) \\
N=1050\end{array}$ & $\begin{array}{l}42655.7 \\
(141898.0) \\
N=2600\end{array}$ & $\begin{array}{l}161047.6 \\
(414018.4) \\
N=2280\end{array}$ & $\begin{array}{l}43880.0 \\
(160801.7) \\
N=3200\end{array}$ & $\begin{array}{l}13440.3 \\
(45696.1) \\
N=2200\end{array}$ & $\begin{array}{l}32105.6 \\
(151955.5) \\
N=4650\end{array}$ \\
\hline $\begin{array}{l}\text { Deflated value } \\
\text { added }\end{array}$ & $\begin{array}{l}23877.8 \\
(49469.8) \\
N=1032\end{array}$ & $\begin{array}{l}10310.3 \\
(23959.4) \\
N=2521\end{array}$ & $\begin{array}{l}15480.8 \\
(68315.6) \\
N=2207\end{array}$ & - & $\begin{array}{l}4191.1 \\
(13275.0) \\
N=2146\end{array}$ & $\begin{array}{l}10277.4 \\
(196707.1) \\
N=4540\end{array}$ \\
\hline Employment & $\begin{array}{l}334.9 \\
(696.5) \\
N=1050\end{array}$ & $\begin{array}{l}129.5 \\
(381.1) \\
N=2600\end{array}$ & $\begin{array}{l}145.6 \\
(392.9) \\
N=2280\end{array}$ & $\begin{array}{l}150.2 \\
(448.8) \\
N=3152\end{array}$ & $\begin{array}{l}61.3 \\
(209.1) \\
N=2200\end{array}$ & $\begin{array}{l}100.4 \\
(327.9) \\
N=4636\end{array}$ \\
\hline $\begin{array}{l}\text { Deflated turnover } \\
\text { per employee }\end{array}$ & $\begin{array}{l}1505.8 \\
(11192.2) \\
\mathrm{N}=1050\end{array}$ & $\begin{array}{l}709.7 \\
(3463.3) \\
N=2600\end{array}$ & $\begin{array}{l}8318.3 \\
(55807.0) \\
N=2280\end{array}$ & $\begin{array}{l}842.8 \\
(12290.9) \\
N=3152\end{array}$ & $\begin{array}{l}310.5 \\
(633.0) \\
N=2200\end{array}$ & $\begin{array}{l}283.5 \\
(709.8) \\
N=4636\end{array}$ \\
\hline $\begin{array}{l}\text { Deflated value } \\
\text { added per } \\
\text { employee }\end{array}$ & $\begin{array}{l}307.9 \\
(3039.1) \\
N=1032\end{array}$ & $\begin{array}{l}248.4 \\
(5821.4) \\
N=2521\end{array}$ & $\begin{array}{l}567.1 \\
(1781.3) \\
N=2207\end{array}$ & - & $\begin{array}{l}88.1 \\
(161.3) \\
N=2146\end{array}$ & $\begin{array}{l}73.5 \\
(180.8) \\
N=4526\end{array}$ \\
\hline Age & $\begin{array}{l}19.5 \\
(18.6) \\
N=845\end{array}$ & $\begin{array}{l}23.0 \\
(19.7) \\
N=2230\end{array}$ & $\begin{array}{l}29.0 \\
(225.7) \\
N=2008\end{array}$ & $\begin{array}{l}19.9 \\
(16.4) \\
N=2765\end{array}$ & $\begin{array}{l}15.0 \\
(11.2) \\
N=1876\end{array}$ & $\begin{array}{l}26.8 \\
(23.8) \\
\mathrm{N}=4080\end{array}$ \\
\hline Debt/fixed assets & $\begin{array}{l}2.7 \\
(17.0) \\
N=1050\end{array}$ & $\begin{array}{l}5.6 \\
(26.4) \\
\mathrm{N}=2600\end{array}$ & $\begin{array}{l}93.8 \\
(457.4) \\
N=2274\end{array}$ & $\begin{array}{l}8.3 \\
(149.5) \\
N=3188\end{array}$ & $\begin{array}{l}3.7 \\
(33.4) \\
N=2199\end{array}$ & $\begin{array}{l}5.8 \\
(44.7) \\
N=4637\end{array}$ \\
\hline $\begin{array}{l}\text { Deflated total } \\
\text { assets per } \\
\text { employee }\end{array}$ & $\begin{array}{l}280.4 \\
(1730.3) \\
\mathrm{N}=1050\end{array}$ & $\begin{array}{l}106.4 \\
(647.2) \\
N=2597\end{array}$ & $\begin{array}{l}562.6 \\
(4918.8) \\
N=2247\end{array}$ & $\begin{array}{l}338.7 \\
(5733.9) \\
N=3118\end{array}$ & $\begin{array}{l}49.2 \\
(205.2) \\
N=2194\end{array}$ & $\begin{array}{l}77.0 \\
(433.9) \\
N=4602\end{array}$ \\
\hline
\end{tabular}

Notes: The figures shown above are the mean, standard deviation (in parenthesis) and total number of observations (N). Turnover and value added are deflated by a GDP deflator with 2006 as the base year. Foreign acquisition is defined as any ownership stake crossing a threshold of 10 per cent of total shareholding. 


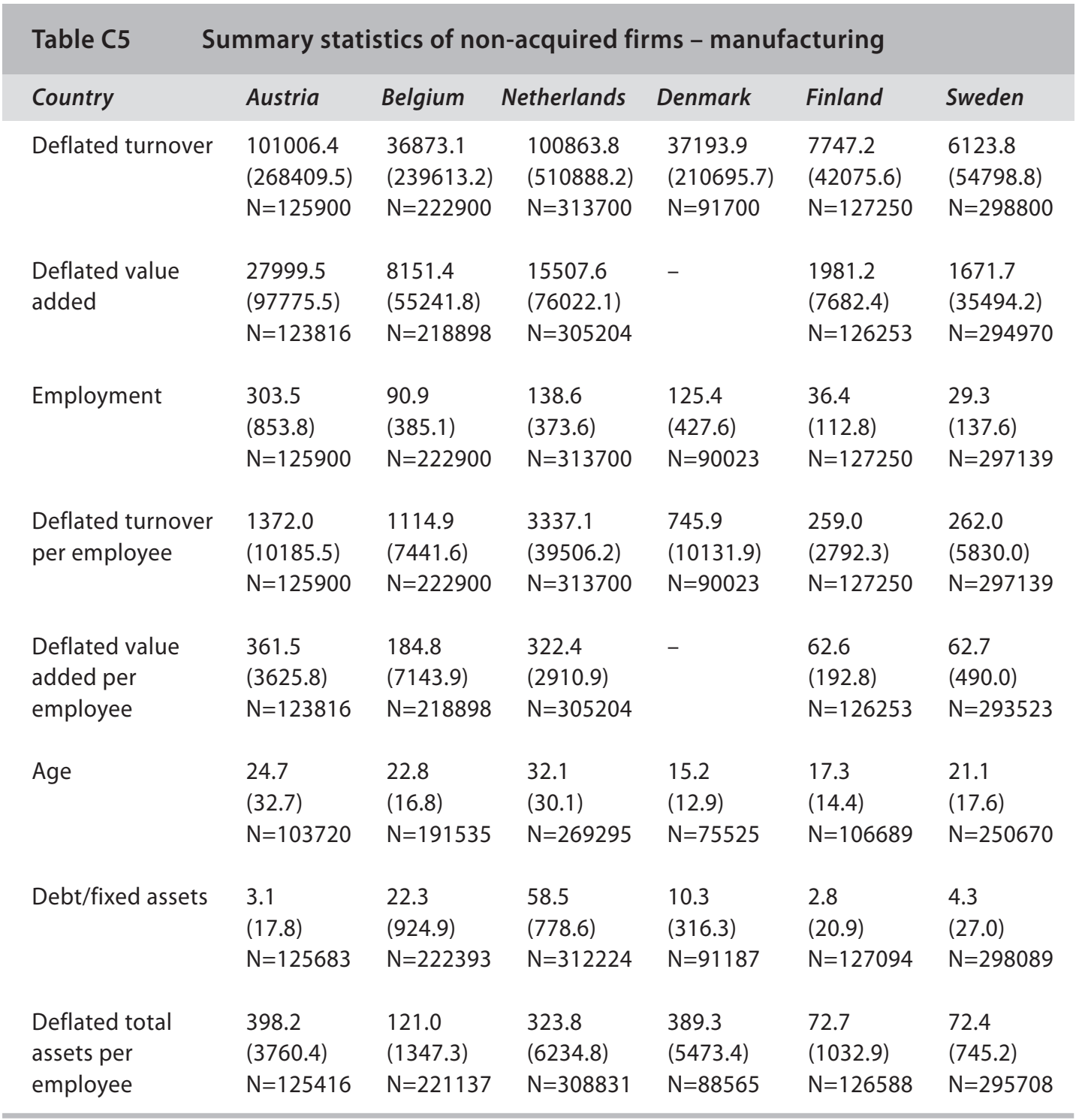

Notes: The figures shown above are the mean, standard deviation (in parenthesis) and total number of observations (N). Turnover and value added are deflated by a GDP deflator with 2006 as the base year. Foreign acquisition is defined as any ownership stake crossing a threshold of 10 per cent of total shareholding. 


\begin{tabular}{|c|c|c|c|c|c|c|}
\hline Table C6 & mary st & tics of all & firms - mar & acturing & & \\
\hline Country & Austria & Belgium & Netherlands & Denmark & Finland & Sweden \\
\hline Deflated turnover & $\begin{array}{l}100886.7 \\
(267398.2) \\
\mathrm{N}=127700\end{array}$ & $\begin{array}{l}36840.8 \\
(237691.1) \\
\mathrm{N}=228350\end{array}$ & $\begin{array}{l}100851.3 \\
(511480.7) \\
\mathrm{N}=320100\end{array}$ & $\begin{array}{l}37451.4 \\
(210703.8) \\
N=97750\end{array}$ & $\begin{array}{l}7918.7 \\
(43223.2) \\
N=136300\end{array}$ & $\begin{array}{l}6525.4 \\
(57148.0) \\
N=309000\end{array}$ \\
\hline $\begin{array}{l}\text { Deflated value } \\
\text { added }\end{array}$ & $\begin{array}{l}27952.8 \\
(97465.5) \\
N=125585\end{array}$ & $\begin{array}{l}8155.7 \\
(54673.0) \\
N=224241\end{array}$ & $\begin{array}{l}15495.5 \\
(75980.5) \\
N=311425\end{array}$ & - & $\begin{array}{l}2044.8 \\
(7832.6) \\
N=135206\end{array}$ & $\begin{array}{l}1804.5 \\
(42392.2) \\
N=304890\end{array}$ \\
\hline Employment & $\begin{array}{l}303.6 \\
(851.3) \\
N=127700\end{array}$ & $\begin{array}{l}91.4 \\
(383.3) \\
N=228350\end{array}$ & $\begin{array}{l}138.6 \\
(373.0) \\
N=320100\end{array}$ & $\begin{array}{l}126.4 \\
(425.8) \\
N=95977\end{array}$ & $\begin{array}{l}37.4 \\
(118.4) \\
N=136300\end{array}$ & $\begin{array}{l}30.6 \\
(142.0) \\
N=307281\end{array}$ \\
\hline $\begin{array}{l}\text { Deflated turnover } \\
\text { per employee }\end{array}$ & $\begin{array}{l}1371.2 \\
(10169.0) \\
\mathrm{N}=127700\end{array}$ & $\begin{array}{l}1104.2 \\
(7382.8) \\
N=228350\end{array}$ & $\begin{array}{l}3330.5 \\
(39497.7) \\
N=320100\end{array}$ & $\begin{array}{l}750.7 \\
(10150.4) \\
N=95977\end{array}$ & $\begin{array}{l}264.8 \\
(3887.3) \\
N=136300\end{array}$ & $\begin{array}{l}262.2 \\
(5734.6) \\
N=307281\end{array}$ \\
\hline $\begin{array}{l}\text { Deflated value } \\
\text { added per } \\
\text { employee }\end{array}$ & $\begin{array}{l}360.3 \\
(3612.6) \\
N=125585\end{array}$ & $\begin{array}{l}184.4 \\
(7085.4) \\
N=224241\end{array}$ & $\begin{array}{l}320.8 \\
(2887.6) \\
N=311425\end{array}$ & - & $\begin{array}{l}63.0 \\
(195.7) \\
N=135206\end{array}$ & $\begin{array}{l}62.9 \\
(482.8) \\
N=303396\end{array}$ \\
\hline Age & $\begin{array}{l}24.6 \\
(32.5) \\
N=105230\end{array}$ & $\begin{array}{l}22.8 \\
(16.8) \\
N=196305\end{array}$ & $\begin{array}{l}32.2 \\
(30.1) \\
N=274970\end{array}$ & $\begin{array}{l}15.5 \\
(13.3) \\
N=80765\end{array}$ & $\begin{array}{l}17.2 \\
(14.2) \\
N=114594\end{array}$ & $\begin{array}{l}21.2 \\
(17.7) \\
N=259665\end{array}$ \\
\hline Debt/fixed assets & $\begin{array}{l}3.1 \\
(17.7) \\
N=127480\end{array}$ & $\begin{array}{l}21.9 \\
(913.8) \\
N=227842\end{array}$ & $\begin{array}{l}58.2 \\
(774.5) \\
N=318598\end{array}$ & $\begin{array}{l}10.6 \\
(339.8) \\
N=97214\end{array}$ & $\begin{array}{l}2.8 \\
(20.8) \\
N=136139\end{array}$ & $\begin{array}{l}4.3 \\
(28.2) \\
N=308257\end{array}$ \\
\hline $\begin{array}{l}\text { Deflated total } \\
\text { assets per } \\
\text { employee }\end{array}$ & $\begin{array}{l}396.4 \\
(3740.0) \\
N=127211\end{array}$ & $\begin{array}{l}120.2 \\
(1333.5) \\
N=226576\end{array}$ & $\begin{array}{l}322.6 \\
(6197.3) \\
N=315139\end{array}$ & $\begin{array}{l}387.1 \\
(5497.2) \\
N=94445\end{array}$ & $\begin{array}{l}71.5 \\
(1004.8) \\
N=135604\end{array}$ & $\begin{array}{l}72.5 \\
(739.5) \\
N=305752\end{array}$ \\
\hline
\end{tabular}

Notes: The figures shown above are the mean, standard deviation (in parenthesis) and total number of observations (N). Turnover and value added are deflated by a GDP deflator with 2006 as the base year. Foreign acquisition is defined as any ownership stake crossing a threshold of 10 per cent of total shareholding. 


\section{References}

Aitken, B. and A. Harrison (1999): "Do domestic firms benefit from direct foreign investment? Evidence from Venezuela", The American Economic Review, Vol. 89, 605-18.

Aitken, B., A. Harrison and R. E. Lipsey (1996): "Wages and foreign ownership A comparative study of Mexico, Venezuela, and the United States", Journal of International Economics, Vol. 40(3-4), 345-71.

Almeida, R. (2007): "The labor market effects of foreign owned firms", Journal of International Economics, Vol. 72, 75-96.

Andridge R. R. and R. J. A. Little (2010): "A review of hot deck imputation for survey non-response". International Statistical Review, Vol. 78(1), 40-64.

Arellano, M. and S. R. Bond (1991): "Some tests of specification of panel data: Monte Carlo evidence and an application to employment equations", Review of Economic Studies, Vol. 58(2), 277-297.

Arndt, C. and A. Mattes (2010): "Cross-Border Mergers and Acquisitions of Multinational Firms. New FirmLevel Evidence", IAW Discussion Papers No. 62.

Arnold, J. M. and B. S. Javorcik (2009): "Gifted kids or pushy parents? Foreign direct investment and plant productivity in Indonesia", Journal of International Economics, Vol. 79, 42-53.

Aw, B. Y., X. Chen and M. J. Roberts (2001): "Firm-Level Evidence on Productivity Differentials and Turnover in Taiwanese Manufacturing", Journal of Development Economics, Vol. 66(1), 51-86.

Balsvik, R. and S. A. Haller (2010): “Picking 'Lemons' or Picking 'Cherries'? Domestic and Foreign Acquisitions in Norwegian Manufacturing", Scandinavian Journal of Economics, Vol. 112(2), 361-87.

Bandick, R. (2011): "Foreign Acquisition, Wages and Productivity", The World Economy, Vol. 34(6), 931-51.

Bandick, R. and H. Görg (2010): “Foreign acquisition, plant survival, and employment growth”, Canadian Journal of Economics, Vol. 43(2), 547-73.

Bandick, R. and P. Hansson (2009): "Inward FDI and demand for skills in manufacturing firms in Sweden", Review of World Economics, Vol. 145(1), 111-31.

Bandick, R. and P. Karpaty (2011): "Employment Effects of Foreign Acquisition", International Review of Economics and Finance, Vol. 20(2), 211-24.

Bartel, A. P. and F.R. Lichtenberg (1987). "The Comparative Advantage of Educated Workers in Implementing New Technology", Review of Economics and Statistics, 69(1), 1-11.

Bellak, C. (2004): "How Domestic and Foreign Firms Differ and Why Does it Matter?", Journal of Economic Surveys, Vol. 18(4), 483-514.

Bellak, C., M. Pfaffermayr and M. Wild (2006): "Firm Performance after Ownership Change: A Matching Estimator Approach", Applied Economics Quarterly, Vol. 52(1), pp. 29-54.

Benfratello, L. and A. Sembenelli (2006): "Foreign ownership and productivity: Is the direction of causality so obvious?", International Journal of Industrial Organization, Vol. 24, 733-51.

Bernard, A. B. and J. B. Jensen (1995): "Exporters, Jobs, and Wages in U.S. Manufacturing: 1976-1987", Brookings Papers on Economic Activity, Microeconomics 1, 67-119. 
Bertrand, O. H. and Zitouna (2008): "Domestic versus cross-border acquisitions: which impact on the target firms' performance?", Applied Economics, Vol. 40, 2221-38.

Blomström, M. and F. Sjöholm (1999): "Technology transfers and spillovers: does local participation with multinationals matter?" European Economic Review, Vol. 43, 915-23.

Bloom, N., R. Sadun and J. Van Reenen (2012): "Americans Do IT Better: US Multinationals and the Productivity Miracle", American Economic Review, Vol. 102(1), 167-201.

Branstetter, L. G. (2001): "Are Knowledge Spillovers International or Intranational in Scope? Microeconometric Evidence from the U.S. and Japan", Journal of International Economics, Vol. 53(1), 53-79.

Caves, R. E. (1971): "International corporations: the industrial economics of foreign investment", Economica, Vol. 38(149), 1-27.

Caves, R. E. (1974): "Multinational Firms, Competition, and Productivity in Host-Country Markets", Economica, Vol. 41(162), 176-93.

Caves, R. E. (1996): Multinational Enterprise and Economic Analysis, Cambridge University Press, Cambridge.

Caves, D. W., L. R. Christensen and W. E. Diewert (1982): "Multilateral Comparisons of Output, Input, and Productivity Using Superlative Index Numbers", The Economic Journal, Vol. 92, 73-86.

Chari, A., W. Chen and K. M. E. Dominguez (2009): "Foreign Ownership and Firm Performance: EmergingMarket Acquisitions in the United States", NBER Working Paper No. 14786.

Chen, W. (2011): "The effect of investor origin on firm performance: Domestic and foreign direct investment in the United States", Journal of International Economics, 83(2), 219-28.

Chhibber, P. K. and S. K. Majumdar (1999): "Foreign Ownership and Profitability: Property Rights, Control, and the Performance of Firms in Indian Industry", Journal of Law and Economics, Part 1, Vol. 42(1), 209-38.

Conyon, M. J., S. Girma, S. Thompson and P. W. Wright (2002a): “The Productivity and Wage Effects of Foreign Acquisition in the United Kingdom", The Journal of Industrial Economics, Vol. L(1), 85-102.

Conyon, M. J., S. Girma, S. Thompson and P. W. Wright (2002b): “The impact of mergers and acquisitions on company employment in the United Kingdom", European Economic Review, Vol. 46(1), 31-49.

Criscuolo, C. and R. Martin (2009): "Multinationals and U.S. Productivity Leadership: Evidence from Great Britain", Review of Economics \& Statistics, Vol. 91(2), 263-81.

Csengödi, S., R. Jungnickel and D. M. Urban (2008): "Foreign Takeovers and Wages in Hungary”, Review of World Economics, Vol. 144(1), 55-82.

Dimelis, S. and H. Louri (2002): "Foreign ownership and production efficiency: a quantile regression analysis", Oxford Economic Papers, Vol. 54, 449-469.

Dunning, J. (1977): "Trade, Location of Economic Activities and MNE: A Search for an Eclectic Approach", in Ohlin, B., P.O. Hesselborn, and P.M. Wickman (eds.) The International Allocation of Economic Activity, London: MacMillan, 395-418.

Dunning, J. (1998): "Location and the Multinational Enterprise: A Neglected Factor?", Journal of International Business Studies, Vol. 29(1), 45-66. 
Findlay, R. (1978): “Relative Backwardness, Direct Foreign Investment, and the Transfer of Technology: A Simple Dynamic Model", Quarterly Journal of Economics, Vol. 92(1), 1-16.

Fortanier, F. and S. J. V. Moons (2011): "Foreign Investors in the Netherlands: Heterogeneous Employment and Productivity Effects", De Economist, Vol. 159, 511-31.

Fukao, K., K. Ito and H.U. Kwon (2005): "Do out-in M\&As bring higher TFP to Japan? An empirical analysis based on micro-data on Japanese manufacturing firms", Journal of the Japanese and International Economies, Vol. 19(2), 272-301.

Fukao, K., K. Ito, H. U. Kwon and M. Takizawa (2008): “Cross-Border Acquisitions and Target Firms' Performance: Evidence from Japanese Firm-Level Data", published in T. Ito and A. K. Rose: International Financial Issues in the Pacific Rim: Global Imbalances, Financial Liberalization, and Exchange Rate Policy, (NBER-EASE Volume 17), 347-89.

Fukao, K. and Y. Murakami (2005): "Do Foreign Firms Bring Greater Total Factor Productivity to Japan?", Journal of the Asia Pacific Economy, Vol. 10(2), 237-54.

Gioia, C. and S. Thomsen (2004): "International Acquisitions in Denmark 1990-1997: Selection and Performance", Applied Economics Quarterly, Vol. 50(1), 61-87.

Girma, S. (2005a): "Safeguarding Jobs? Acquisition FDI and Employment Dynamics in U.K. Manufacturing", Review of World Fconomics, Vol. 141(1), 165-78.

Girma, S. (2005b): "Technology Transfer from Acquisition FDI and the Absorptive Capacity of Domestic Firms: An Empirical Investigation", Open Economies Review Vol. 16, 175-87.

Girma, S. and H. Görg (2004): “Blessing or Curse? Domestic Plants' Survival and Employment Prospects After Foreign Acquision", Applied Economics Quarterly, Vol. 50(1), pp. 89-110.

Girma, S. and H. Görg (2007): "Multinationals' Productivity Advantage: Scale or Technology?" Economic Inquiry, Vol. 45(2), 350-62.

Girma, S., H. Görg and M. Pisu (2008): "Exporting, linkages and productivity spillovers from foreign direct investment", Canadian Journal of Economics, Vol. 41(1), 320-40.

Girma, S., D. Greenaway and K. Wakelin (2001): "Who Benefits from Foreign Direct Investment in the UK?", Scottish Journal of Political Economy, Vol. 48(2), 119-33.

Girma, S., R. Kneller and M. Pisu (2007): “Do exporters have anything to learn from foreign multinationals?", European Economic Review, Vol. 51, 981-98.

Gong,Y., H. Görg and S. Maioli (2007): "Employment Effects of Privatisation and Foreign Acquisition of Chinese State-owned Enterprises", International Journal of the Economics of Business, Vol. 14(2), 197-214.

Greenaway, D., A. Guariglia and Z. Yu (2009): “The More the Better? Foreign Ownership and Corporate Performance in China", University of Nottingham Research Paper 2009/05.

Gugler, K., D. C. Mueller, B. B. Yurtoglu and C. Zulehner (2003): "The effects of mergers: an international comparison", International Journal of Industrial Organization, Vol. 21, 625-53.

Gugler, K. and B. B. Yurtoglu (2004): "The effects of mergers on company employment in the USA and Europe" International Journal of Industrial Organization, Vol. 22, 481-502. 
Hanley, A. and V. Zervos (2007): "The Performance of UK Takeovers: Does the Nationality of Acquirers Matter?", International Journal of the Economics of Business, Vol. 14(2), 283-97.

Harris, R. (2009): The Effect of Foreign Mergers and Acquisitions on UK Productivity and Employment, Report Submitted to UKTI October 2009.

Harris, R. and C. Robinson (2002): "The Effect of Foreign Acquisitions on Total Factor Productivity: PlantLevel Evidence from U.K. Manufacturing, 1987-1992", Review of Economics and Statistics, Vol. 84(3), 562-68.

Heckman, J., Ichimura, H., and P. Todd (1997): "Matching as an Econometric Evaluation Estimator: Evidence from Evaluating a Job Training Programme", Review of Economic Studies, Vol. 64(4), 605-54.

Helpman, E. (2006): "Trade, FDI, and the Organization of Firms", Journal of Economic Literature, Vol. XLIV, 589-630.

Helpman, E., M. J. Melitz and S. R. Yeaple (2004): "Export Versus FDI with Heterogeneous Firms", The American Economic Review, Vol. 94(1), 300-16.

Huttunen, K. (2007): "The Effect of Foreign Acquisition on Employment and Wages: Evidence from Finnish Establishments", Review of Economics \& Statistics, Vol. 89(3), 497-509.

Ilmakunnas, P. and M. Maliranta (2004): "Foreign medicine: a treatment effect analysis of the productivity effects of foreign ownership", Applied Economics Quarterly, 50(1), 41-59.

International Monetary Fund (1993): Balance of Payments Manual, 5th ed. (Washington).

Javorcik, B. S. (2004): "Does Foreign Direct Investment Increase the Productivity of Domestic Firms? In Search of Spillovers Through Backward Linkages", The American Economic Review, Vol. 94(3), 605-27.

Jensen, M.C. (1986): "Agency Costs of Free Cash Flow, Corporate Finance and Takeovers", American Economic Review, Vol. 76(2), 323-29.

Karpaty, P. (2007): "Productivity Effects of Foreign Acquisitions in Swedish Manufacturing: The FDI Productivity Issue Revisited", International Journal of the Economics of Business, Vol. 14(2), 241-60.

Keller, W. (2004): "International Technology Diffusion”, Journal of Economic Literature, Vol. 42(3), 752-82.

Lapan, H. and P. K. Bardhan (1973): “Localized Technical Progress and Transfer of Technology and Economic Development", Journal of Economic Theory, Vol. 6(6), 585-95.

Lehto, E. and P. Böckerman (2008): "Analysing the employment effects of mergers and acquisitions", Journal of Economic Behavior \& Organization, Vol. 68(1), 112-24.

Levinsohn, J. and A. Petrin (2003): “Estimating production functions using inputs to control for unobservables", Review of Economic Studies Vol. 70(2), 317-42.

Lipsey, R. E., F. Sjöholm and J. Sun (2010): “Foreign Ownership and Employment Growth in Indonesian Manufacturing", NBER Working Paper No. 15936.

Maliranta, M. and S. Nurmi (2004): “Do Foreign Players Change the Nature of the Game Among Local Entrepreneurs?", ETLA Discussion Papers No. 942.

Maliranta, M. and S. Nurmi (2007): “Does Foreign Presence Stimulate Creative Destruction in Local Markets", ETLA Discussion Papers No. 1114. 
Mattes, A. (2010a): "International M\&A: Evidence on Effects of Foreign Takeovers", IAW Discussion Papers No. 60 .

Mattes, A. (2010b): “The Impact of Horizontal and Vertical FDI on Labor Demand for Different Skill Groups", IAW Discussion Papers Nr. 59.

Mander, A. (2003): "WHOTDECK: Stata Module to Perform Multiple Imputation Using the Approximate Bayesian Bootstrap with Weights". Statistical Software Components S433201, Boston College Department of Economics, revised 21 Feb 2011. Downloadable at http://fmwww.bc.edu/repec/bocode/w/whotdeck.ado

Mander, A. P. and Clayton, D. (2003) "Weighted Hotdeck Imputation”.

Downloadable at http://fmwww.bc.edu/repec/bocode/w/whotdeck.pdf

Nelson, R. R. and E. S. Phelps (1966): "Investment in humans, technological diffusion, and economic growth", American Economic Review, Vol. 56, 69-75.

Nocke, V. and S. Yeaple (2007): “Cross-border mergers and acquisitions vs. greenfield foreign direct investment: The role of firm heterogeneity", Journal of International Economics, Vol. 72, 336-65.

Olley, G. and A. Pakes (1996): "The Dynamics of Productivity in the Telecommunications Equipment Industry", Econometrica, 64, 1263-79.

Piscitello, L. and L. Rabbiosi (2005): "The Impact of Inward FDI on Local Companies' Labour Productivity: Evidence from the Italian Case", International Journal of the Economics of Business, Vol. 12(1), 35-51.

Roll, R. (1986): "The Hubris Hypothesis of Corporate Takeovers", Journal of Business, Part 1, Vol. 59(2), $197-216$.

Rubin, D. B. (1987): Multiple Imputation for Nonresponse in Surveys. New York: John Wiley and Sons.

Salis, S. (2008): "Foreign Acquisition and Firm Productivity: Evidence from Slovenia", The World Economy, Vol. 31(8), 1030-48.

Schiffbauer, M., I. Siedschlag and F. Ruane (2009): “Do Foreign Mergers and Acquisitions Boost Firm Productivity?", ESRI Working Paper No. 305.

Törnqvist, L. (1936), “The Bank of Finland's Consumption Price Index", Bank of Finland Monthly Bulletin, No. $10,1-8$.

Vahter, P. (2011): “Does FDI Spur Productivity, Knowledge Sourcing and Innovation by Incumbent Firms? Evidence from Manufacturing Industry in Estonia", The World Economy, Vol. 34(8), 1308-26.

Vickers, J. (1995): “Concepts of Competition”, Oxford Economic Papers, Vol. 47(1), 1-23. 



\section{Aikaisemmin ilmestynyt ETLA Raportit-sarjassa (ennen ETLA Keskusteluaiheita) Previously published in the ETLA Reports series (formerly ETLA Discussion Papers)}

No 1284 Jože Damijan - Stefanie A. Haller - Ville Kaitila - Mika Maliranta - Emmanuel Milet - Matija Rojec, The Performance of Trading Firms in the Services Sectors - Comparable Evidence from Four EU Countries. 6.9.2012. $40 \mathrm{p}$.

No 1285 Tuomo Nikulainen - Julia Salmi, Uudistaminen ja yhteistyöverkostot Suomen teollisuudessa. Havaintoja yrityskyselystä. 14.9.2012. $23 \mathrm{~s}$.

No 1286 Tuomo Nikulainen - Antti-Jussi Tahvanainen - Martti Kulvik, Expectations, Reality and Performance in the Finnish Biotechnology Business. 19.9.2012. 25 p.

No 1287 Matias Kalm - Timo Seppälä, Palaako tuotanto Aasiasta Suomeen? Case Polkupyörä. 19.9.2012. 24 s.

No 1288 Timo Seppälä - Martin Kenney, Competitive Dynamics, IP Litigation and Acquisitions. The Struggle for Positional Advantage in the Emerging Mobile Internet. 4.10.2012. 30 p.

No $1 \quad$ Nuutti Nikula - Markku Kotilainen, Determinants for Foreign Direct Investment in the Baltic Sea Region. 6.11.2012. 30 p.

No 2 Olavi Rantala, EU:n ilmastopolitiikan talousvaikutukset vuoteen 2020. 26.11.2012. $44 \mathrm{~s}$.

No 3 Jukka Lassila - Tarmo Valkonen, Julkisen talouden rahoituksellinen kestävyys. 21.1.2013. 26 s.

No 4 Jukka Lassila - Niku Määttänen - Tarmo Valkonen, Kuntaeläkkeiden rahoitus ja kunnalliset palvelut. 30.1.2013. $30 \mathrm{~s}$.

No $5 \quad$ Niku Määttänen - Tarmo Valkonen, Asunnot eläkkeiksi? 18.2.2013. 26 s.

Sarjan julkaisut ovat raportteja tutkimustuloksista ja väliraportteja tekeillä olevista tutkimuksista.

Julkaisut ovat ladattavissa pdf-muodossa osoitteessa: www.etla.fi » julkaisut » raportit

Papers in this series are reports on research results and on studies in progress.

Publications in pdf can be downloaded at www.etla.fi » publications » reports

\section{ETLA}

